\author{
UNITED STATES \\ DEPARTMENT OF THE INTERIOR \\ GEOLOGICAL SURVEY \\ Water Resources Division
}

\title{
DATA FOR SPRINGS IN THE NORTHERN COAST RANGES AND \\ KLAMATH MOUNTAINS OF CALIFORNIA
}

\section{By}

C. F. Berkstresser, Jr.

Prepared in cooperation with the California Department of Water Resources

\author{
OPEN-FILE REPORT
}

\author{
Menlo Park, California \\ October 1968
}





\section{CONTENTS}

Introduction-0.

Purpose and scope-

Previous investigations-

Mineral constituents in spring water

Selected references-

\section{1}

2

2

3

IIIUSTRATION

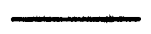

Figure 1. Index map-

\section{APPENDIXES}

A. Description of springs-

B. Chemical and spectrographic analyses- 


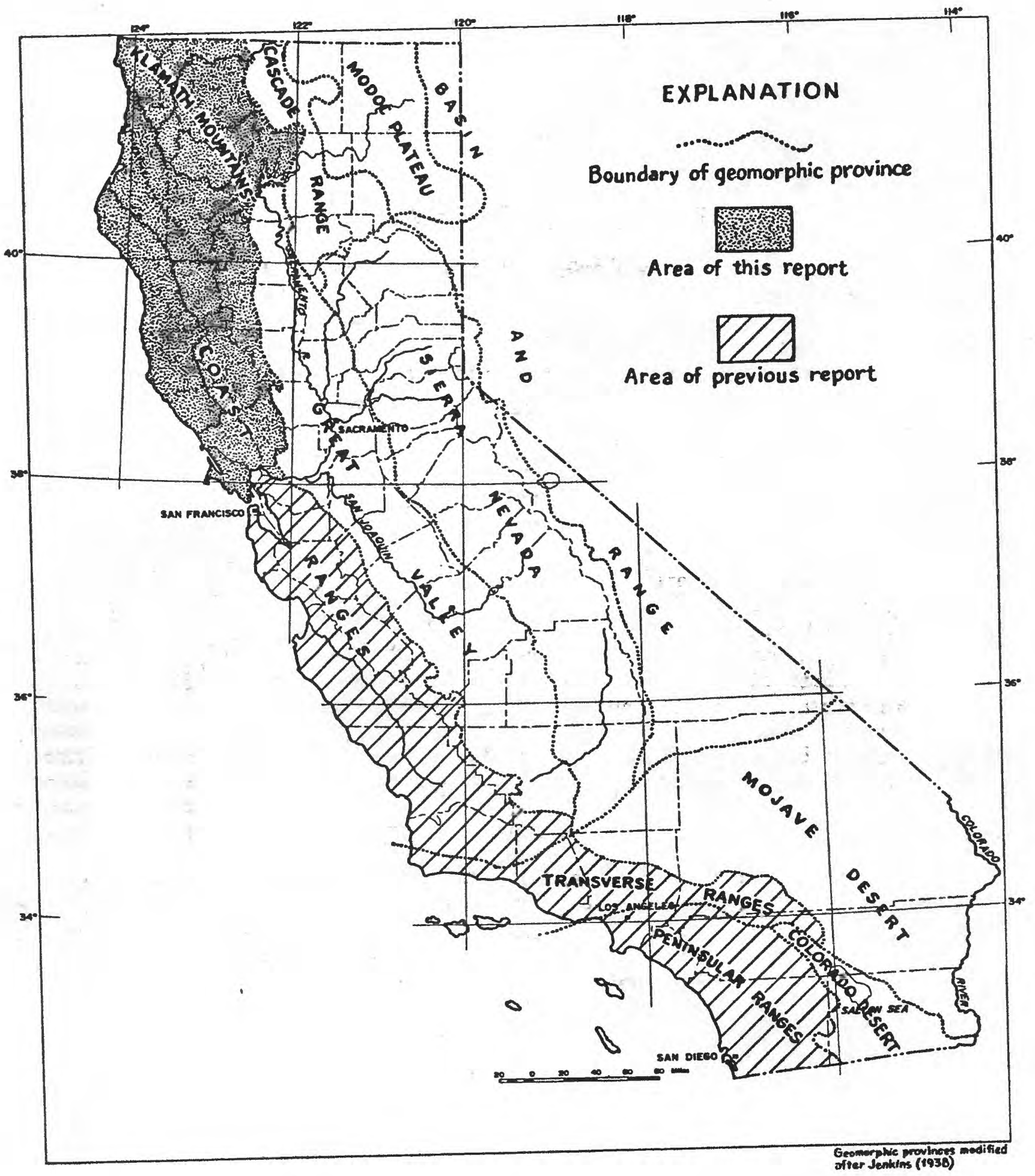

Figure 1._Index map. 
DATA FOR SPRINGS IN THE NORTHERN COAST RANGES AND

KIAMATH MOUNTAINS OF CAIIFORNIA:

By C. F. Berkstresser, Jr.

\section{INTRODUCTION}

The area covered in this investigation includes the coast Ranges north of San Francisco and the Klamath Mountains northward to the Oregon border (fig. 1). The area probably includes more than 100,000 springs, but only about 200 are described here. Appendix A describes 223 springs, spring groups, and a few wells that have been designated as springs by their owners. Appendix B lists the results of chemical analyses of water from 204 springs. Because many springs occur in groups of two or more and the chemical quality of water from each of the springs in a group is often similar, one analysis has been used to represent a group. Both appendixes list the spring data alphabetically by county, and within each county, numerically by township and range.

In a few instances wells are designated as springs. In most cases, these are flowing wells that have been developed for use by health resorts and are named as springs on maps, or are ingrained in the literature as springs. A conscious effort has been made to avoid naming new springs which are in fact wells. 
The purpose of this report is to provide basic data about selected springs in the Coast Ranges and Klamath Mountains of California north of San Francisco. The scope of this report includes description of the springs and the results of up-to-date analyses of water from the springs.

Criteria used to select springs for this study included accessibility, availability of previous data, and geologic or hydrologic significance. Temperature and $\mathrm{pH}$ were measured at the spring site and ammonium was determined qualitatively since January 1963. Flow from springs was measured or estimated, depending on the situation at each site. The location of each site was determined on topographic or other available maps. Chemical and spectrographic analyses were made by personnel of the U.S. Geological Survey. Analyses include most of the major, minor, and trace inorganic constituents that occur in natural water.

This report represents the direct or indirect effort of many people who supplied information and aided in collection of samples. Individuals employed by the U.S. Forest Service, the California Division of Forestry, and the California state Library were of particular help.

\section{Previous Investigations}

Two statewide reports on springs have been published. Anderson (1890) described about 200 springs in California. Waring (1915) described about 590 spring areas representing nearly 1,600 springs; he included about 300 chemical analyses for 250 springs. A comprehensive tabulation of thermal springs throughout the United States, including California, was made by Stearns and others (1937) and by Waring (1965). Other reports that describe springs in California include the works of Whitney (1865), Gilbert (1875), Peale (1886; 1894), Becker (1888), Crook (1899), Clarke (1924), and Fitch (1927). A report by Berkstresser (1968) that is similar to this one has been released; the report describes springs in the southern coast, Transverse, and Peninsular Ranges of California (fig. 1).

Additional descriptions of springs and analyses of their water have been published in many areal reports that describe water resources, mineral deposits, and geology. The references at the end of this report list many such reports and include all publications cited above or in appendix A. 
All natural water contains dissolved mineral matter. Water in contact with soil or rock, even for a few minutes, will dissolve some mineral or organic materials. This is one part of the weathering process. The type and quantity of dissolved matter depends on many variables such as the type of rocks or soils, the length of time of contact, and the tenperature.

The mineral constituents and physical properties of natural water reported in the table of analyses (appendix B) include those that have a praetical bearing on the value of the water for most domestic and industrial purposes. Others, such as the trace metals, may presently be only of academic interest but may assume importance as knowledge of the relation of water quality to health grows. Analyses include results for silica, arsenic, mercury, calcium, magnesium, strontium, barium, sodium, potassium, lithium, nitrogen as ammonia, bicarbonate, carbonate, sulfate, chloride, fluoride, nitrate, phosphate, boron, $\mathrm{pH}$, sum of the determined constituents, and specific conductance. In addition, many analyses include spectrographic determinations for trace metals, aluminum, beryllium, bismuth, cadmium, cobalt, chromium, copper, iron, galiium, germanium, manganese, molybdenum, nickel, lead, titanium, vanadium, and zinc.

The chemistry of natural water has been described by Hem (1959) and White and others (1963), and standards of chemical quality for domestic, industrial, and irrigation use are available (U.S. Salinity Laboratory Staff, 1954; U.S. Public Health Service, 1962; McKee and Wolf, 1963; and Pomeroy and Orlob, 1967). 
SELECTED REFERENCES

Albers, J. P., 1964, Geology of the French Gulch quadrangle, Shasta and Trinity Counties, California: U.S. Geol. Survey Bull. 1141-J, 70 p.

Allen, E. T., and Day, A. L., 1927, Steam wells and other thermal activity at "The Geysers," California: Carnegie Inst. Washington Pub. 378, 106 p.

American Public Health Association and others, 1965, Standard methods for the examination of water, sewage, and industrial wastes: New York, Am. Public Health Assoc. Inc., 12th ed., 769 p.

Anderson, C. A., 1936, Volcanic history of the Clear Lake area, California: Geol. Soc. America Bull., v. 47, no. 5, p. 629-664.

Anderson, Winslow, 1890, Mineral springs and health resorts of California: San Francisco, Calif., The Bancroft Co., 384 p.

Averill, C. V., 1929a, Glenn County, in Twenty-fifth Report of the State Mineralogist: California Div. Mines and Mining, v. 25, chap. 4, p. 418-426.

1929b, Lake County, in Twenty-fifth Report of the State Mineralogist:

California Div. Mines and Mining, v. 25, chap. 3, p. 337-365.

1929c, Mendocino County, in Twenty-fifth Report of the State Mineralogist:

California Div. Mines and Mining, v. 25, chap. 4, p. $456-467$.

1929d, Napa County, in Twenty-fifth Report of the State Mineralogist:

California Div. Mines and Mining, v. 25, chap. 2, p. 213-242.

1939, Mineral resources of Shasta County, in Thirty-fifth Report of the State Mineralogist: California Jour. Mines and Geology, v. 35, chap. 2, p. 108-191.

1941, Mineral resources of Trinity County, in Thirty-seventh Report of the State Mineralogist: California Jour. Mines and Geology, v. 37, chap. I, p. 8-89.

1947, Mines and mineral resources of Lake County, California:

California Jour. Mines and Geology, v. 43, no. 1, p. 15-40.

Averitt, Paul, 1945, Quicksilver deposits of the Knoxwell district, Napa, Yolo, and Lake Counties, California, in Forty-first Report of the State Mineralogist: California Jour. Mines and Geology, v. 41, chap. 2, p. $65-89$.

Back, William, 1957, Geology and ground-water features of the Smith River plain, Del Norte County, California: U.S. Geol. Survey Water-Supply Paper 1254, $76 \mathrm{p}$. 
Bailey, E. H., 1959, Froth veins, formed by immiscible hydrothermal fluids, in mercury deposits, California: Geol. Soc. America Bull., v. 70, no. 5 , p. 661-663.

ed., 1966, Geology of northern California: California Div. Mines and Geology Bull. 190, 508 p.

Bailey, E. H., Irwin, W. P., and Jones, D. I., 1964, Franciscan and related rocks, and their significance in the geology of western California: California Div. Mines and Geology Bull. 183, 177 p.

Barnes, Ivan, LaMarche, V. C., Jr., ed., and Himmelberg, Glen, 1967, Geochemical evidence of present-day serpentinization: Science, v. 156, no. 3776 (May 12, 1967), p. 830-832.

Becker, G. F., 1888, Geology of the quicksilver of the Pacific slope: U.S. Geol. Survey Mon. 13, 486 p.

Berkstresser, C. F., Jr., 1968, Data for springs in the southern Coast, Transverse, and Peninsular Ranges of California: U.S. Geol. Survey open-file rept., 21 p., 2 apps.

Borisenko, L. F., 1963, Some characteristics of the distribution of gallium in ultramatic rocks: Geokhimiya (in translation) no. 8, p. $778-785$.

Bowen, 0. E., Jr., ed., 1962, Geologic guide to the oil and gas fields of northern California: California Div. Mines and Geology Bull. 181, $412 \mathrm{p}$.

Bradley, W. W., 1916a, Colusa County, in Fourteenth Report of the State Mineralogist: California State Mining Bur., v. 14, pt. 2, p. 175-196.

1916b, Glenn County, in Fourteenth Report of the State Mineralogist:

California State Mining Bur., v. 14, pt. 2, p. 197-201.

1916c, Lake County, in Fourteenth Report of the State Mineralogist:

California State Mining Bur., v. 14, pt. 2, p. 202-240.

1916d, Marin County, in Fourteenth Report of the State Mineralogist:

California State Mining Bur.; v. 14, pt. 2, p. 241-261.

1916e, Napa County, in Fourteenth Report of the State Mineralogist:

California State Mining Bur., v. 14, pt. 2, p. 262-299.

1916f, Solano County, in Fourteenth Report of the State Mineralogist:

California State Mining Bur., v. 14, pt. 2, p. 300-315.

$1916 \mathrm{~g}$, Sonoma County, in Fourteenth Report of the State Mineralogist:

California State Mining Bur., v. 14, pt. 2, p. 316-366. 
Bradley, W. W., 1916h, Yolo County, in Fourteenth Report of the State Mineralogist: California state Mining Bur., v. 14, pt. 2, p. 367-370. 1918, Quicksilver resources of California, with a section on Metallurgy and ore-dressing: California State Mining Bur. Bull. 78, 389 p.

1946, Observations at "The Geysers," Sonoma County, California, in Forty-second Report of the State Mineralogist: California Jour. Mines and Geology, v. 42, chap. 3, p. 295-298.

Brice, J. C., 1953, Geology of the Lower Lake quadrangle: California Div. Mines Bull. 166, $72 \mathrm{p}$.

Brooks, B. C., Rogers, Donald, Day, Paul, and Wootton, Tom, 1962, Field trip I, Sacramento Valley, in Geologic guide to the oil and gas fields of northern California: California Div. Mines and Geology Bull. 181, p. 369-380.

Brown, G. C., 1916a, Shasta County, in Fourteenth Report of the State Mineralogist: California State Mining Bur., v. 14, pt. 6, p. 747-809.

1916b, Siskiyou County, in Fourteenth Report of the State Mineralogist: California State Mining Bur., v. 14, pt. 6, p. 810-872.

1916c, Trinity County, in Fourteenth Report of the State Mineralogist: California State Mining Bur., v. 14, pt. 6, p. 873-925.

Brown, R. D., Jr., 1964, Thrust-fault relations in the northern Coast Ranges, California: Art. 123 in U.S. Geol. Survey Prof. Paper 475-D, p. D7-D13.

Brown, R. D., Jr., and Rich, E. I., 1961, Geologic map of the Lodoga quadrangle, Glenn and Colusa Counties, California: U.S. Geol. Survey Oil and Gas Inv. Map OM-210.

California Department of Water Resources, 1964a, Faults and earthquake epicenters in California, in Crustal strain and fault movement investigation: California Dept. Water Resources, Bull. 116-2, 96 p.

Cardwell, G. T., 1958a, Data for wells and streams in the Russian and upper Eel River valleys, Sonoma and Mendocino Counties, California: U.S. Geol. Survey open-file rept., $198 \mathrm{p}$.

1958b, Geology and ground water in the Santa Rosa and Petaluma Valley areas, Sonoma County, California: U.S. Geol. Survey Water-Supply Paper 1427, $273 \mathrm{p}$.

1965, Geology and ground water in Round, Laytonville, and Little Valleys, Sonoma and Mendocino Counties, California: U.S. Geol. Survey WaterSupply Paper 1548, $154 \mathrm{p}$. 
Carlson, C. R., 1962, Oil seeps and early petroleum development in norther California, in Geologic guide to the oil and gas fields of northern California: California Div. Mines and Geology Bull. 181, p. 23-26.

Cater, F. W., Jr., and Wells, F. G., 1953, Geology and mineral resources of the Gasquet quadrangle, California-Oregon: U.S. Geol. Survey Bull. 995-c, p. 79-132.

Clarke, F. W., 1924, The data of geochemistry, 5th ed.: U.S. Geol. Survey Bull. 770,841 p.

Coy, 0. C., 1923, California County boundaries: Berkeley, California Historical Survey Comm., 335 p.

Crook, J. K., 1899, The mineral waters of the United States and their therapeutic uses: New York, Lea Bros. and Co, 588 p.

Crowell, J. C., 1962, Displacement along the San Andreas fault, California Geol. Soc. America Spec. Rept. 71, 61 p.

Davis, F. F., 1948, Mines and mineral resources of Napa County, California: California Jour. Mines and Geology, v. 44, chap. 2, p. 159-188.

Davis, G. A., 1966, Metamorphic and granitic history of the Klamath Mountains, California, in Geology of northern California: California Div. Mines and Geology Bull. 190, p. 39-50.

Dole, R. B., 1912, Concentration of mineral water in relation to therapeutic activity, in Matson, G. C., The production of mineral waters in 1911: U.S. Geol. Survey Mineral Resources U.S., 1911, p. 43-60.

Evenson, R. E., 1959, Geology and ground-water features of the Eureka area, Humboldt County, California: U.S. Geol. Survey Water-Supply $1470,80 \mathrm{p}$.

Everhart, D. L., 1946, Quicksilver deposits at the Sulphur Bank mine, Lake County, California, in Forty-second Report of the State Mineralogist: California Jour. Mines and Geology, v. 42, chap. 2, p. 125-153.

1950, Skaggs Springs quicksilver mine, Sonoma County, California: California Jour. Mines and Geology, v. 46, no. 3, p. 385-394.

Fenneman, N. M., 1931, Physiography of western United States: New York, McGraw-Hill Book Co., Inc., 534 p.

Feth, J. H., 1966, Nitrogen compounds in natural water - a review: Water Resources Research, v. 2, no. 1, p. 41-58. 
Feth, J. H., Rogers, S. M., and Roberson, C. E., 1961, Aqua de Ney, California, a spring of unique chemical character: Geochim. et Cosmochim. Acta, v. 22, p. 75-86.

Fitch, W. E., 1927, Mineral waters of the United States and American spas: Philadelphia, Pa., Lea and Febiger, 798 p.

Forstner, William, 1903, The quicksilver resources of California: California Div. Mines Bull. 27, 273 p.

Garrels, R. M., 1960, Mineral equilibria at low temperature and pressure: New York, Harper, 254 p.

Gay, T. E., Jr., and Aune, Q. A., 1958, Geologic map of California, Alturas sheet: California Div. Mines.

Gealey, W. K., 1951, Geology of the Healdsburg quadrangle, California: California Div. Mines Bull. 161, 70 p.

Gilbert, G. K., 1875, Report on the geology of portions of California, Nevada, Utah, Colorado, New Mexico, and Arizona, examined in the years 1871, 1872, and 1873, in Wheeler, G. M., Geology, pt. I: U.S. Geog. and Geol. Surveys W. looth Meridian, v. 3, p. 17-187.

Gudde, E. G., 1962, California place names, $2 d$ ed.: Berkeley, Calif., Univ. Press, $383 \mathrm{p}$.

Hawkes, H. E., and Webb, J. S., 1962, Geochemistry in mineral exploration: New York, Harper and Row, $415 \mathrm{p}$.

Hem, J. D., 1959, Study and interpretation of the chemical characteristics of natural water: U.S. Geol. Survey Water-Supply Paper 1473, 269 p.

Hinds, N. E. A., 1952, Evolution of the California landscape: California Div. Mines Bull. 158, $240 \mathrm{p}$.

Irwin, W. P., 1960, Geologic reconnaissance of the northern Coast Ranges and Klamath Mountains, California: California Div. Mines Bull. 179, $80 \mathrm{p}$.

1966, Geology of the Klamath Mountains province, in Geology of northern California: California Div. Mines and Geology Bull. 190, p. 19-38.

Jenkins, 0. P., 1938, Geomorphic map of California: California Div. Mines. ed., 1943, Geologic formations and economic development of the oil and gas fields of California: California Div. Mines Bull. 118, 773 p.

Jennings, C. W., 1968, Point Arena Hot Springs: California Div. Mines and Geology Mineral Inf. Service, v. 2l, no. 4, 61 p. 
Jennings, C. W., and Burnett, J. L., 1961, Geologic map of California, San Francisco sheet: California Div. Mines.

Jennings, C. W., and Strand, R. G., 1960, Geologic map of California, Ukiah sheet: California Div. Mines.

Kirby, J. M., 1943, Sites region, in Geologic formations and economic development of the oil and gas fields of California: California Div. Mines Bull. 118, pt. 3, p. 606-608.

Koenig, J. B., 1963, Geologic map of California, Santa Rosa sheet: California Div. Mines and Geology.

1966, Geothermal resources in California: California Div. Mines and Geology Mineral Inf. Service, v. 19, no. 6, p. 94-95.

Kropotkin, P. N., 1960, The geological conditions for the appearance of life on the earth, and the problems of petroleum genesis, in Florkin, Marcel, ed. Aspects of the origin of life: New York, Pergamon Press, p. 63-73.

Kraynov, S. R., 1967, Geochemistry of germanium in thermal carbonate waters (illustrated by examples from the Pamirs and Greater Cavcasus): Geochemistry (in translation) 1967, v. 4, no. 2, p. 309-320.

Kunkel, Fred, and Upson, J. E., 1960, Geology and ground water in Napa and Sonoma Counties, California: U.S. Geol. Survey Water-Supply Paper 1495, $252 \mathrm{p}$.

Kuroda, Kazoo, 1939, The occurrence of germanium in the hot springs of Senami [Japan]: Bull. Chem. Soc. Japan, v. 14, p. 303-304 (in Chem. Abst., v. 33, p. 8864).

Lachenbruch, M. C., 1962, Geology of the west side of the Sacramento Valley, California, in Geologic guide to the oil and gas fields of northern California: California Div. Mines and Geology Bull. 181, p. 53-66.

LaFehr, T. R., 1965, Gravity, isostasy, and crustal structure in the southern Cascade Range: Jour. Geophys. Research, v. 70, no. 22, p. 5581-5597.

Laizure, C. McK., 1925, Humboldt County, in Twenty-first Report of the State Mineralogist: California State Mining Bur., v. 21, chap. 3, p. 295-324.

1926a, Marin County, in Twenty-second Report of the State Mineralogist: California State Mining Bur., v. 22, chap. 3, p. 314-326.

1926b, Sonoma County, in Twenty-second Report of the State

Mineralogist: California State Mining Bur., v. 22, chap. 3, p. 327-365. 
Lane, A. C., 1908, Mine waters and their field assay: Geol. Soc. America Bull., v. 19, p. 501-512.

Lawson, A. C., 1914, Description of the San Francisco district; Tamalpais, San Francisco, Concord, San Mateo, and Hayward quadrangles: U.S. Geol. Survey Geol. Atlas, Folio 193.

LeGrand, H. E., 1958, Chemical character of water in igneous and metamorphic rocks of North Carolina: Econ. Geology, v. 53, p. 178-189.

Levine, Harry, Rowe, J. J., and Grimaldi, F. S., 1955, Molybdenum blue reaction and determination of phosphorus in waters containing arsenic, silicon, and germanium: Anal. Chemistry, v. 27, no. 2, p. 258-262.

Iogan, C. A., 1925, Siskiyou County, in Twenty-first Report of the State Mineralogist: California State Mining Bur., v. 21, chap. 4, p. 413-498. 1926a, Shasta County, in Twenty-second Report of the State Mineralogist: California State Mining Bur., v. 22, chap. 2, p. 121-201.

1926b, Trinity County, in Twenty-second Report of the State Mineralogist: California state Mining Bur., v. 22, chap. 1, p. 1-67.

1929, Colusa County, in Twenty-fifth Report of the State Mineralogist: California Div. Mines and Mining, v. 25, chap. 3, p. 284-300.

Lowell, F. L., 1916, Mendocino County, in Fourteenth Report of the State Mineralogist: California state Mining Bur., v. 14, pt. 3, p. 415-425.

Lydon, P. A., Gay, T. E., Jr., and Jennings, C. W., 1960, Geologic map of California, Westwood sheet: California Div. Mines.

McClure, C. R., 1956, Geochemistry and migration of meteoric and connate waters as related to geologic structure [Calif.] [abs.]: Am. Assoc. Petroleum Geologists Bull., v. 40, no. 2, 431 p.

McKee, J. E., and Wolf, H. W., 1963, Water quality criteria, 2d ed.: California State Water quality Control Board Pub. 3-A, 548 p.

McNitt, J. R., 1960, Geothermal power: California Div. Mines Mineral Inf. Service, v. 13, no. 3, p. 1-9.

1963, Exploration and development of geothermal power in California: California Div. Mines and Geology Spec. Rept. 75, 45 p.

Mack, Seymour, 1958, Geology and ground-water features of Scott Valley, Siskiyou County, California: U.S. Geol. Survey Water-Supply Paper 1462, $98 \mathrm{p}$.

Mason, Brian, 1958, Principles of geochemistry, 2d ed.: New York, John Wiley and Sons, Inc., $310 \mathrm{p}$. 
Maxson, J. H., 1933, Economic geology of portions of Del Norte and Siskiyou Counties, northwesternmost California, in Twenty-ninth Report of the State Mineralogist: California Jour. Mines and Geology,-v. 29, chap. 1-2, p. 123-160.

Meinzer, 0. E., 1923, Outline of ground-water hydrology with definitions: U.S. Geol. Survey Water-Supply Paper 494, 71 p.

1927, Large springs in the United States: U.S. Geol. Survey WaterSupply Paper 557, $94 \mathrm{p}$.

Oakeshott, G. B., ed., 1959, San Francisco earthquakes of March 1957: California Div. Mines Spec. Rept. 57, p. 7-24.

O'Brien, J. C., 1946, Mines and mining in Tehama County, in Forty-second Report of the State Mineralogist: California Jour. Mines and Geology v. 42, chap. 3, p. 183-195.

1947, Mines and mineral resources of Siskiyou County: California Jour. Mines and Geology, v. 43, no. 4, p. 413-462.

1952, Mines and mineral resources of Del Norte County, California: California Jour. Mines and Geology, v. 48, no. 4, p. 261-309.

1965, Mines and mineral resources of Trinity County, California: California Div. Mines and Geology, County Rept. no. 4, 125 p.

Ogle, B. A., 1953, Geology of Eel River valley area, Humboldt County, California: California Div. Mines Bull. 164, 128 p.

Olmsted, F. H., and Davis, G. H., 1961, Geologic features and groundwater storage capacity of the Sacramento Valley, California:

U.S. Geol. Survey Water-Supply Paper 1497, 241 p.

Peale, A. C., 1886, Lists and analyses of the mineral springs of the United States: U.S. Geol. Survey Bull. 32, 235 p.

1894, Natural mineral waters of the United States: U.S. Geol. Survey 14th Ann. Rept., pt. 2, p. 49-88.

Pomeroy, R. D., and Orlob, G. T., 1967, Problems of setting standards and of surveillance for water quality control: California State Water Quality Control Board Pub. 36, 123 p.

Poole, J. L., 1961, Water-resources reconnaissance of Hoopa Valley, Humboldt County, California: U.S. Geol. Survey Water-Supply Paper 1576-C, p. Cl-Cl8.

Rainwater, F. H., and Thatcher, L. I., 1960, Methods for collection and analysis of water samples: U.S. Geol. Survey Water-Supply Paper 1454, $301 \mathrm{p}$. 
Rankama, K. K., and Sahama, T. G., 1950, Geochemistry: Chicago, Chicago Univ. Press, $912 \mathrm{p}$.

Rist, R. L., and Harrington, w. C., 1943, Paskenta region, in Geologic formations and economic development of the oil and gas fields of California: California Div. Mines Bull. 118, pt. 3, p. 619-620.

Roberson, C. E., and Whitehead, H. C., 1961, Ammoniated thermal waters of Lake and Colusa Counties, California: U.S. Geol. Survey Water-Supply Paper 1535-A, 11 p.

Rubey, W. W., 1951, Geologic history of sea water: Geol. Soc. America Bull., v. 62 , no. 9 , p. $1111-1147$.

Rynearson, G. A., 1946, Chromite deposits of the North Elder Creek area, Tehama County, California: U.S. Geol. Survey Bull. 945-G, p. 191-210.

Sanborn, A. F., 1960, Geology and paleontology of the southwest quarter of the Big Bend quadrangle, Shasta County, California: California Div. Mines Spec. Rept. 63, 26 p.

Scholl, A. W., and Arrick, R. W., Jr., 1955, Germanium bibliography: Huntington, W. Va., $131 \mathrm{p}$.

Scott, R. C., and Barker, F. B., 1962, Data on uranium and radium in ground water in the United States, 1954 to 1957: U.S. Geol. Survey Prof. Paper 426, $115 \mathrm{p}$.

Silvey, W. D., 1961, Concentration method for the spectrochemical determination of minor elements in water: U.S. Geol. Survey Water-Supply Paper 1540-B, p. 11-22.

1967, Occurrence of selected minor elements in the waters of California: U.S. Geol. Survey Water-Supply Paper 1535-L, 25 p.

Silvey, W. D., and Brennan, Robert, 1962, Concentration method for the spectrochemical determination of seventeen minor elements in natural water: Anal. Chem., v. 34, no. 7, p. 784-786.

Simoons, F. J., 1954, Nineteenth century mines and mineral spring resorts of Lake County, California: California Jour. Mines and Geology, v. 50, no. 2, p. 295-319.

Smith, F. G., 1963, Physical geochemistry: Reading, Mass., Addison-Wesley Pub. Co., Inc., $624 \mathrm{p}$.

Stearns, N. D., Stearns, H. T., and Waring, G. A., 1937, Thermal springs in the United States: U.S. Geol. Survey Water-Supply Paper 679-B, p. 59-206. 
Strand, R. G., 1962, Geologic map of California, Redding sheet: Californie Div. Mines and Geology.

1964, Geologic map of California, Weed sheet: California Div. Mines and Geology.

Strand, R. G., and Koenig, J. B., 1965, Geologic map of California, Sacramento sheet: California Div. Mines and Geology.

Taliaferro, N. L., 1943, Geologic history and structure of the central Coast Ranges of California, in Geologic formations and economic development of the oil and gas fields of California: California Div. Mines Bull. 118, pt. 2, p. 119-163.

Thomas, H. E., and White, D. E., 1960, Meteoric versus nonmeteoric ground water: Am. Soc. Civil Engineers Trans. 1960, v. 125, pt. I, p. 1304-1307.

Thomasson, H. G., Jr., Olmsted, F. H., and LeRoux, E. F., 1960, Geology, water resources and usable ground-water storage capacity of part of Solano County, California: U.S. Geol. Survey Water-Supply Paper 1464 . $693 \mathrm{p}$.

Trask, P. D., and others, 1950, Geologic description of the manganese deposits of California: California Div. Mines Bull. 152, 378 p.

Tucker, W. B., 1919, Mines and mineral resources of Tehama County, in Fifteenth Report of the State Mineralogist: California State Mining Bur., v. 15, pt., p. 258-266.

U.S. Geological Survey, 1954, Surface water of the United States, 1952, Part 1l, Pacific slope basins in California: U.S. Geol. Survey Water-Supply Paper 1245, $565 \mathrm{p}$.

U.S. Public Health Service, 1962, Drinking water standards, 1962: U.S. Public Health Service Pub. 956, 6I p.

U.S. Salinity Laboratory Staff, 1954, Diagnosis and improvement of saline and alkali soils: U.S. Dept. Agriculture, Agr. Handb. no. 60, 160 p.

Upson, J. E., and Kunkel, Fred, 1955, Ground water of the Lower LakeMiddletown area, Lake County, California: U.S. Geol. Survey WaterSupply Paper 1297, 83 p.

Ver Planck, W. E., 1955, Mines, mineral resources, and mineral industries of Marin County, California: California Jour. Mines and Geology, v. 51 , no. 3 , p. $221-289$.

Vinogradov, A. P., Florenskii, K. P., and Volynets, V. F., 1963, Ammonia in meteorites and igneous rocks: Geokhimiya (in translation) no. 10, p. 905-916. 
Vonsen, Magnus, 1946, Minerals at "The Geysers," Sonoma County, California in Forty-second Report of the State Mineralogist. California Jour. Mines and Geology, v. 42, chap. 3, p. 287-293.

Waring, G. A., 1915, Springs of California: U.S. Geol. Survey Water-Supply Paper $338,410 \mathrm{p}$.

1965, Thermal springs of the United States and other countries of the world--a summary: U.S. Geol. Survey Prof. Paper 492, 383 p.

Weaver, C. E., 1943, Point Arena-Fort Ross region in Geologic formations and economic development of the oil and gas fields of California:

California Div. Mines Bull. 118, pt. 3, p. 628-632.

1949, Geology and mineral deposits of an area north of San Francisco

Bay, California--Vacaville, Antioch, Mount Vaca, Carquinez, Mare Island, Sonoma, Santa Rosa, Petaluma, and Point Reyes quadrangles: California Div. Mines Bull. 149, 135 p.

Wells, F. G., Cater, F. W., Jr., and Rynearson, G. A., 1946, Chromite deposits of Del Norte County, California, in Geological investigations of chromite in California: California Div. Mines Bull. 134, chap. 1 of pt. 1, p. 1-76.

White, D. E., 1955, Thermal springs and epithermal ore deposits, in Economic geology, 50th anniversary v., 1905-1955: Urbana, Il1., Econ. Geology Pub. Co., p. 99-154.

1957a, Thermal waters of volcanic origin: Geol. Soc. America Bull., v. $68, \mathrm{p} .1637-1658$.

1957b, Magmatic, connate, and metamorphic waters: Geol. Soc. America Bull., v. 68, p. 1659-1682.

White, D. E., Hem, J. D., and Waring, G. A., 1963, Data of geochemistry, 6th ed., Chemical composition of subsurface waters: U.S. Geol. Survey Prof. Paper 440-F, $67 \mathrm{p}$.

Whitney, J. D., 1865, Geology: California Geol. Survey, v. I, 498 p.

Wilson, S. H., 1962, Comments on Aqua de Ney, a spring of unique chemical character: Geochim. et Cosmochim. Acta, v. 26, p. 519-521.

Yates, R. G., and Hilpert, I. S., 1946, Quicksilver deposits of eastern Mayacmas district, Lake and Napa Counties, California, in Forty-second Report of the State Mineralogist: California Jour. Mines and Geology, v. 42, chap. 3, p. 231-286. 

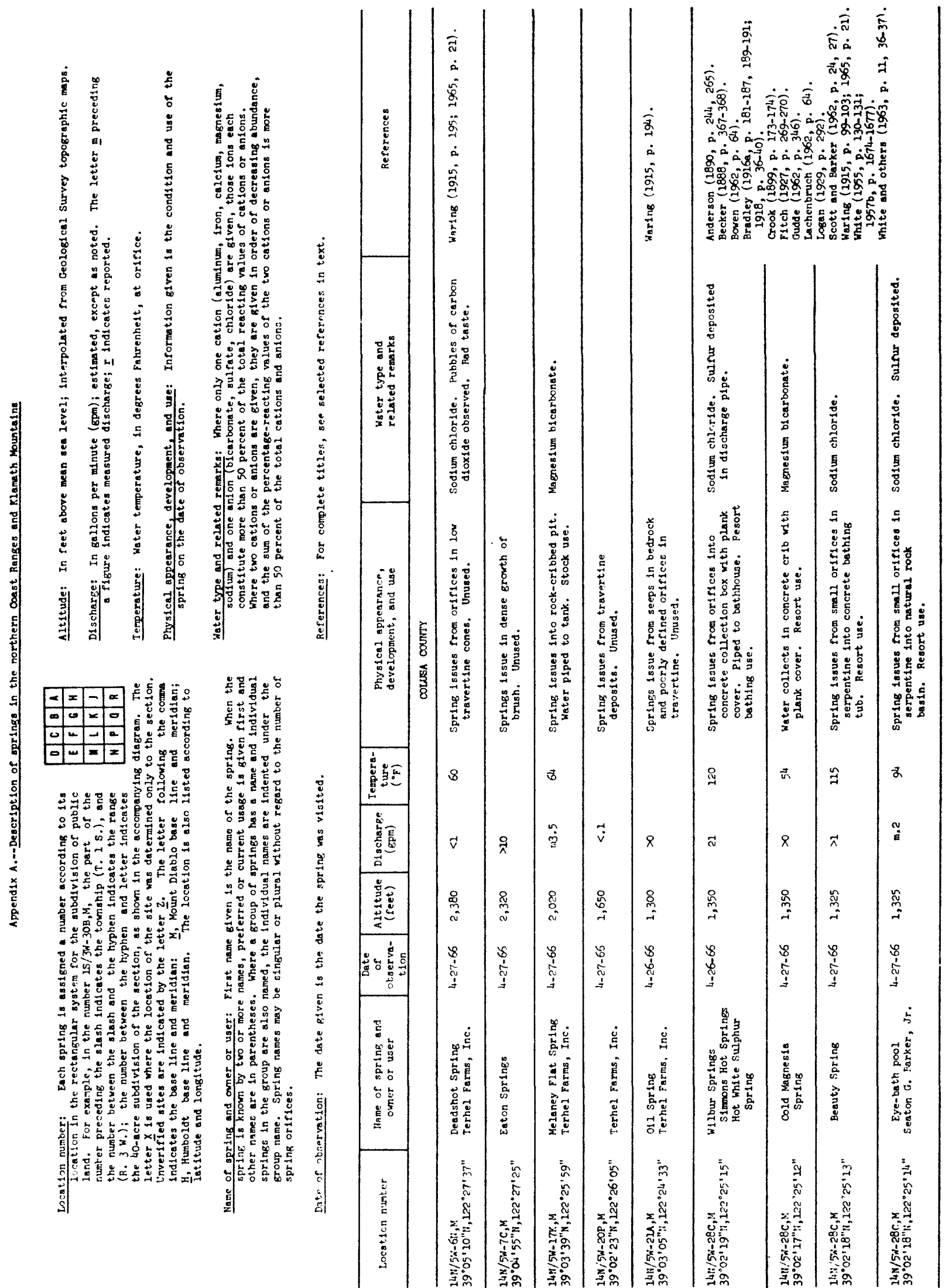


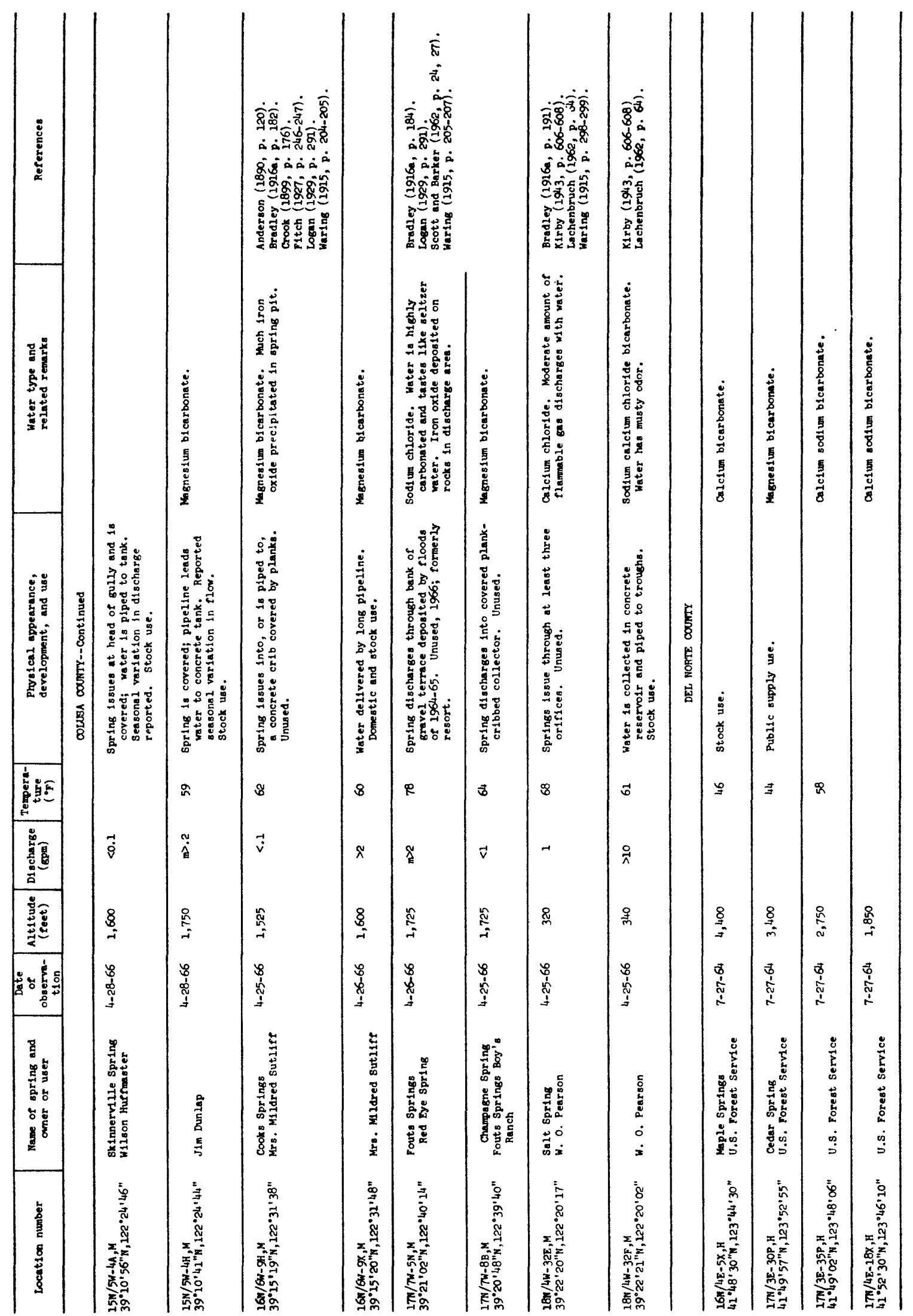




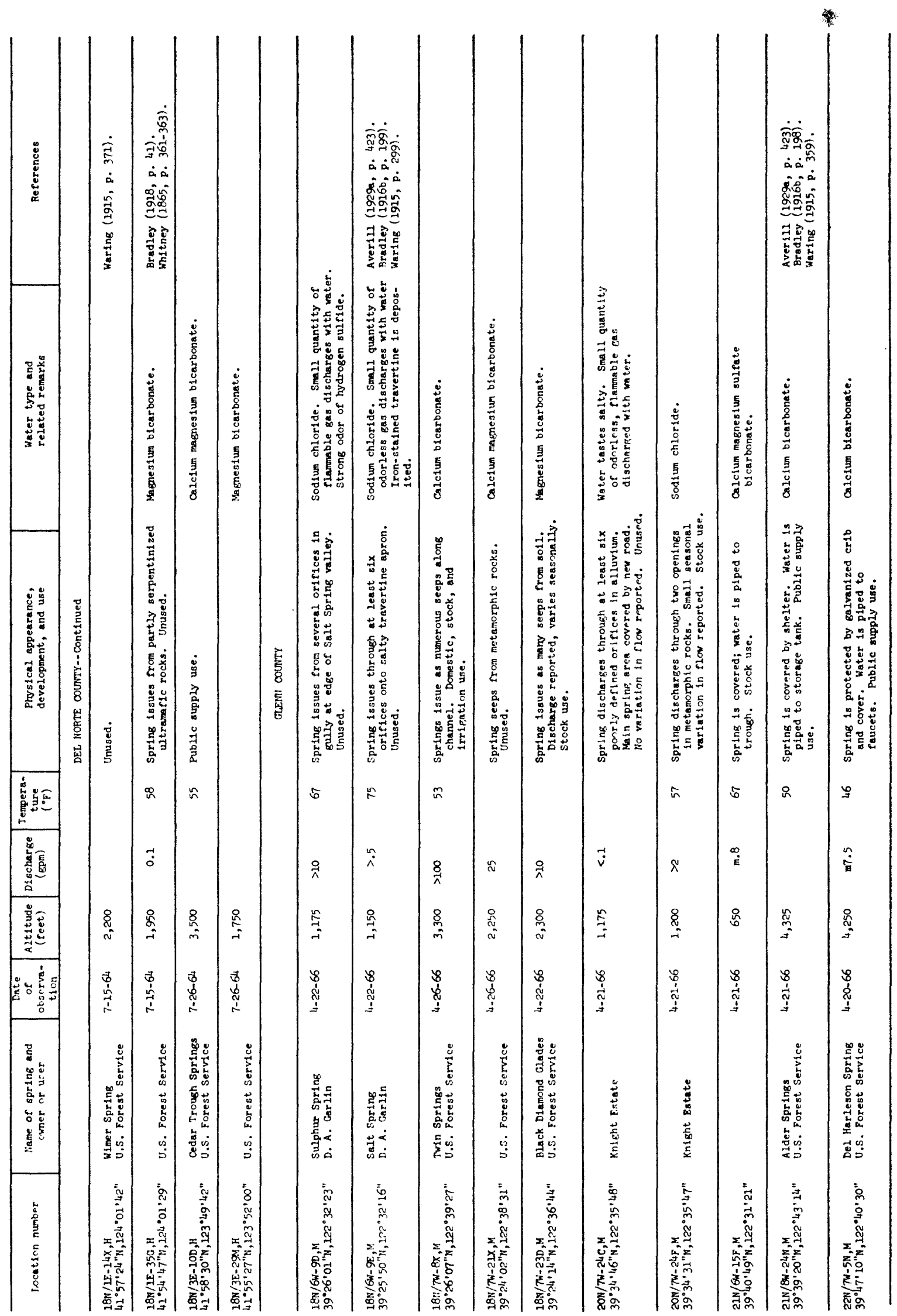




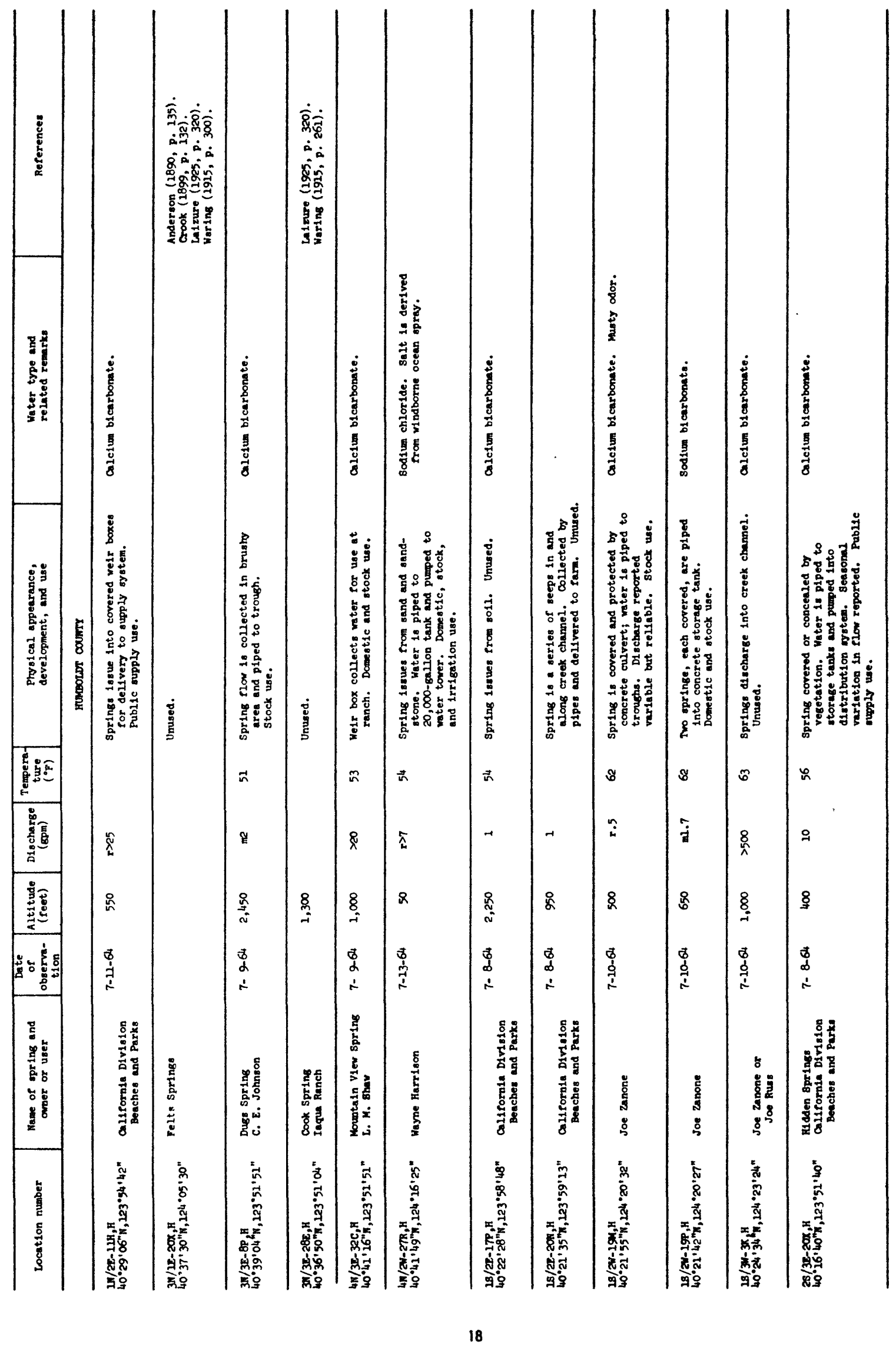




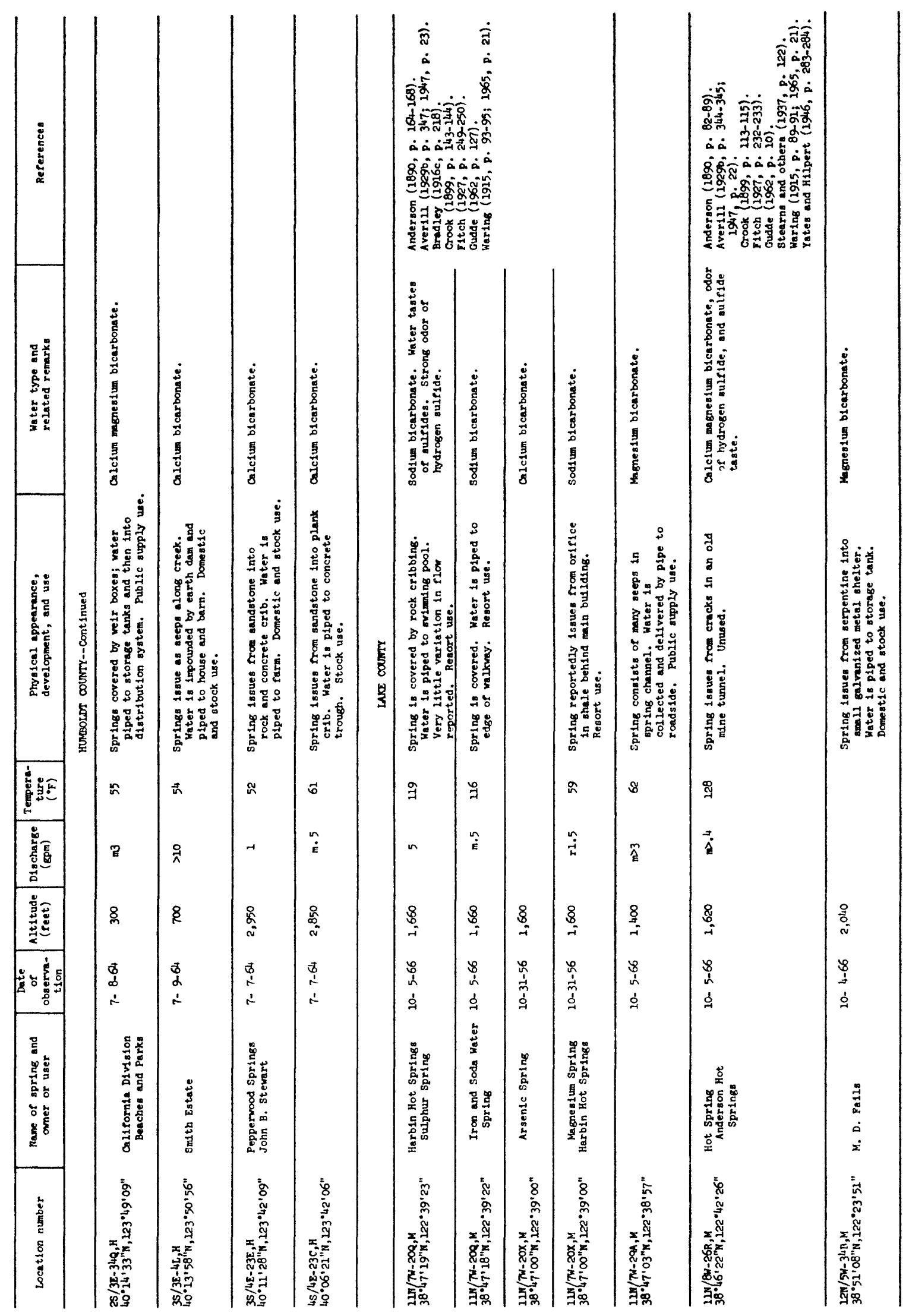




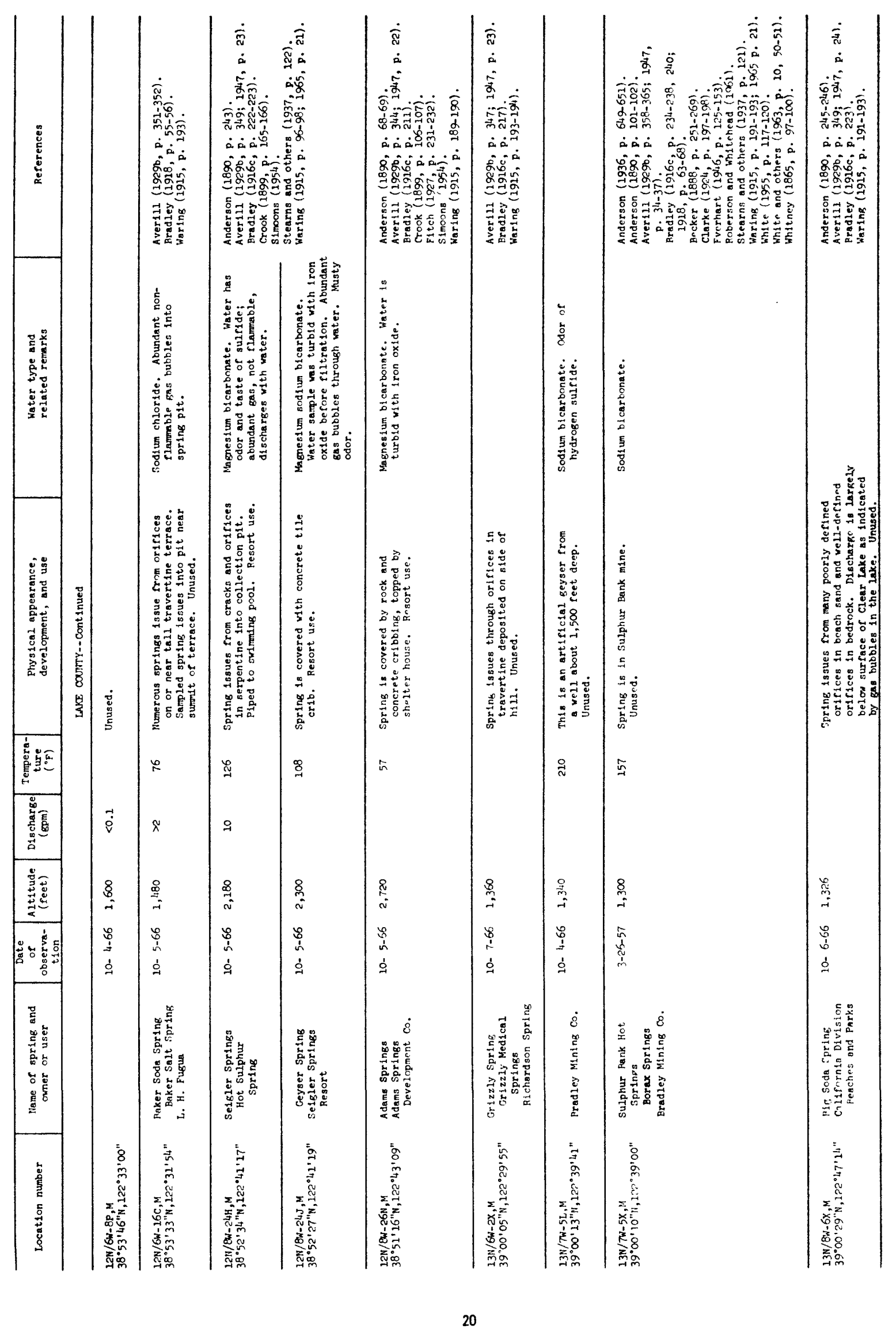




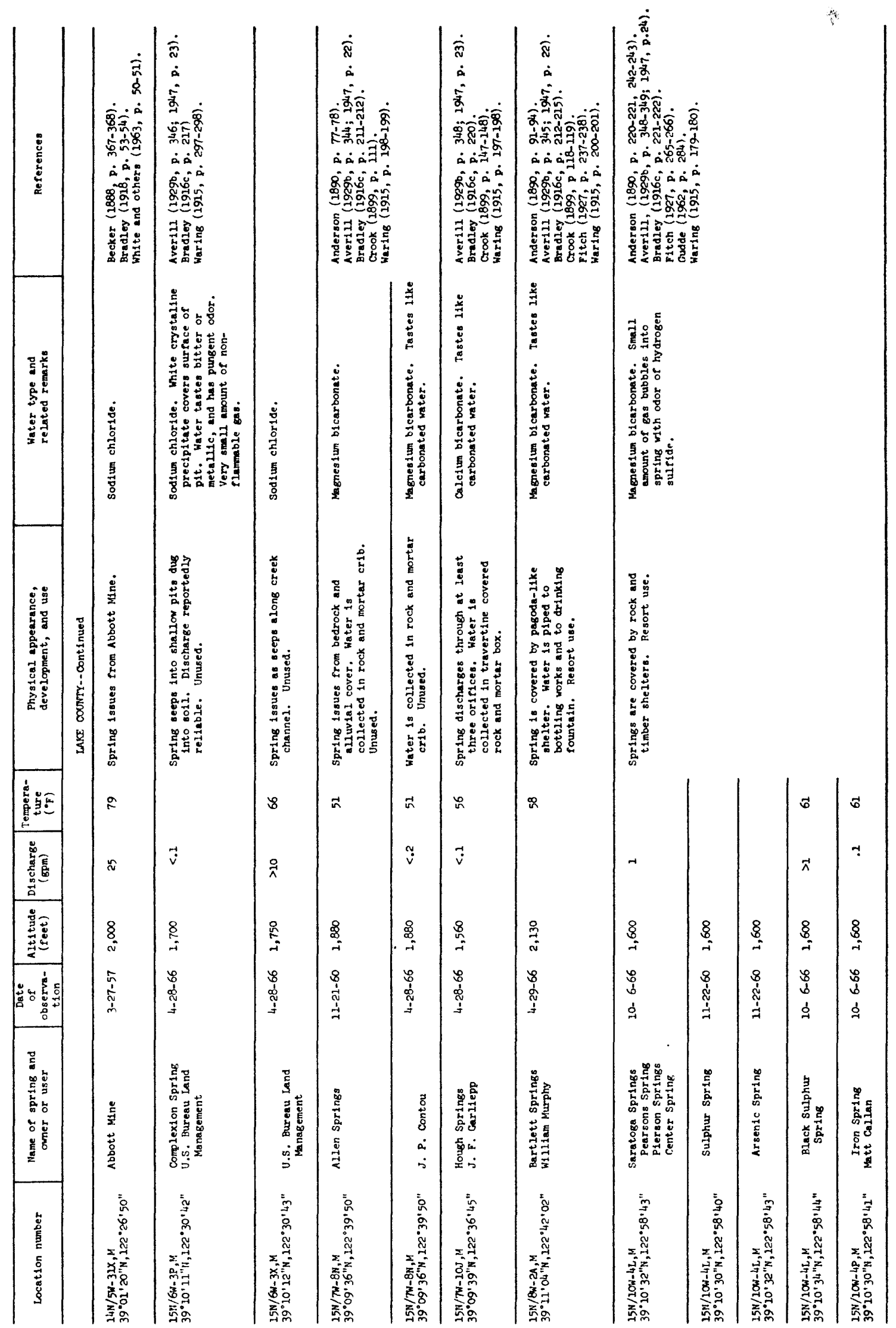




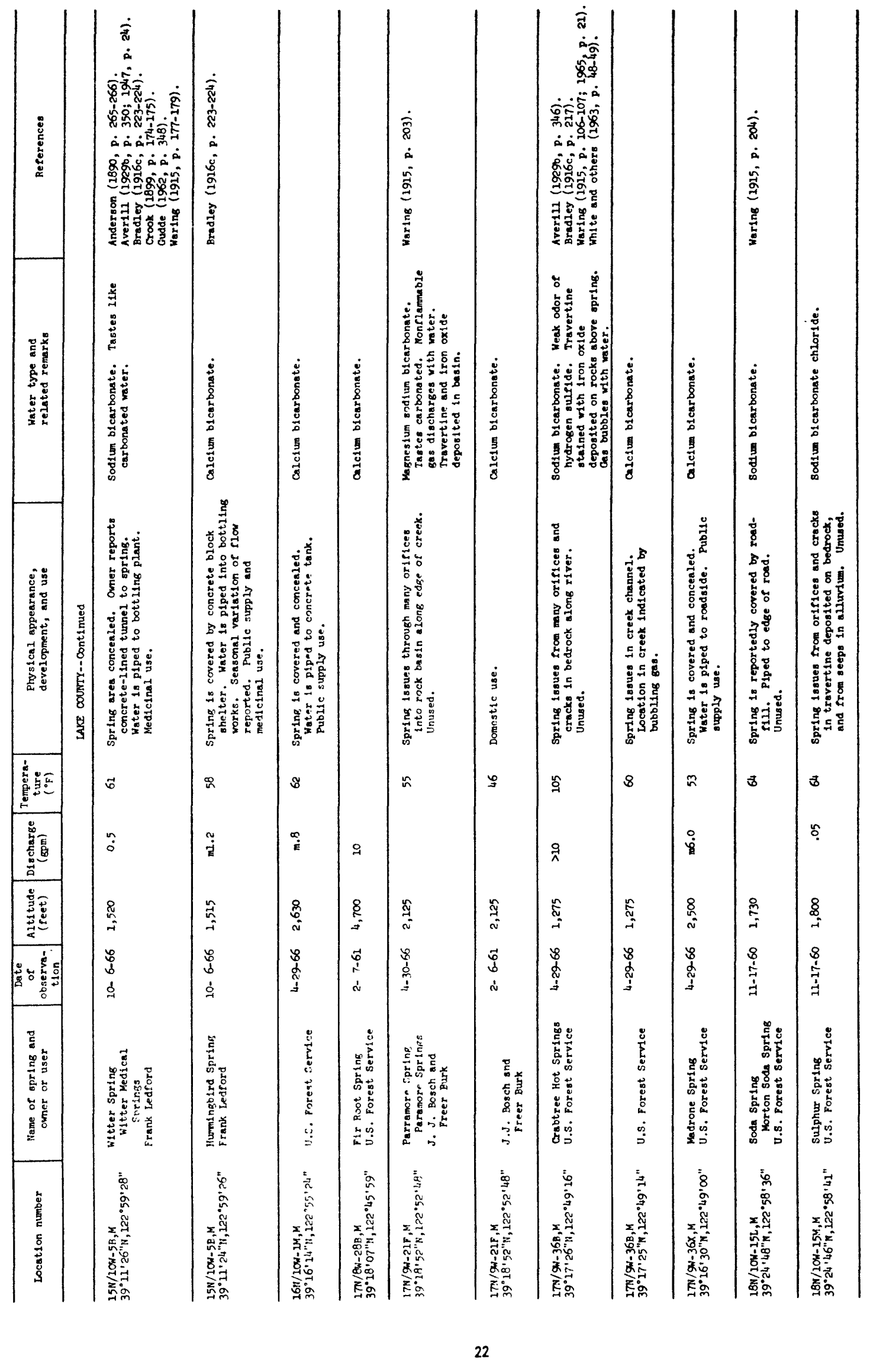




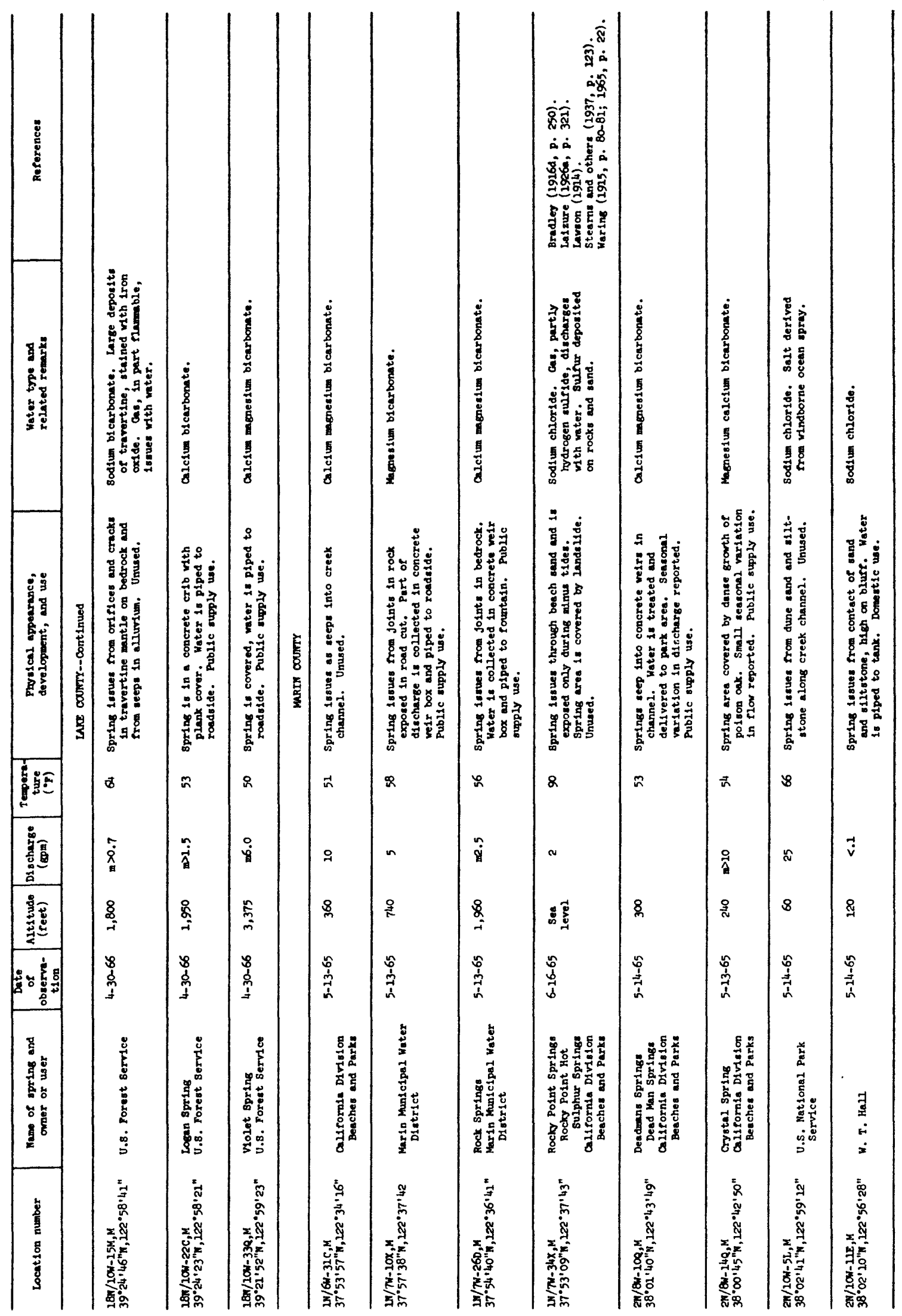




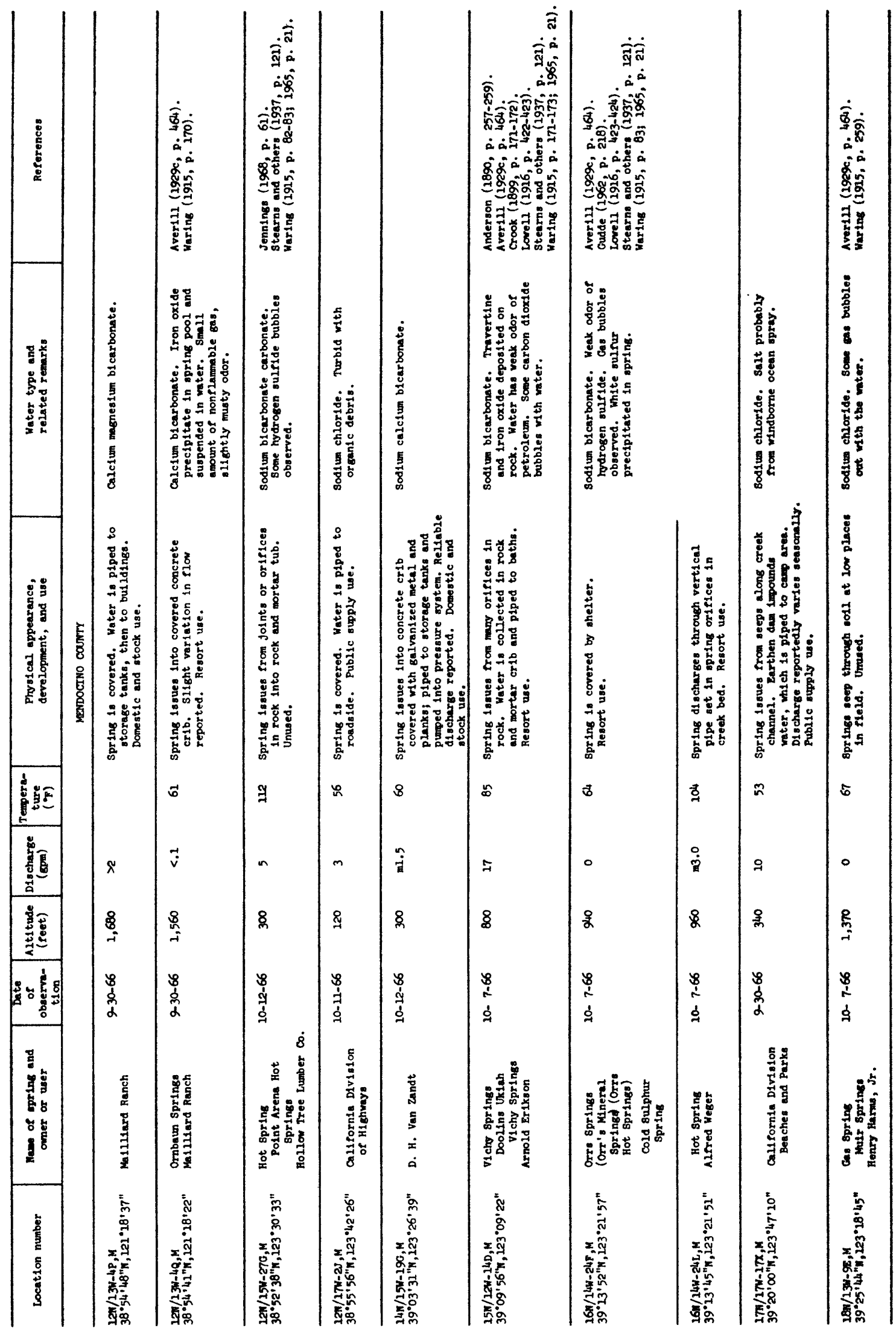




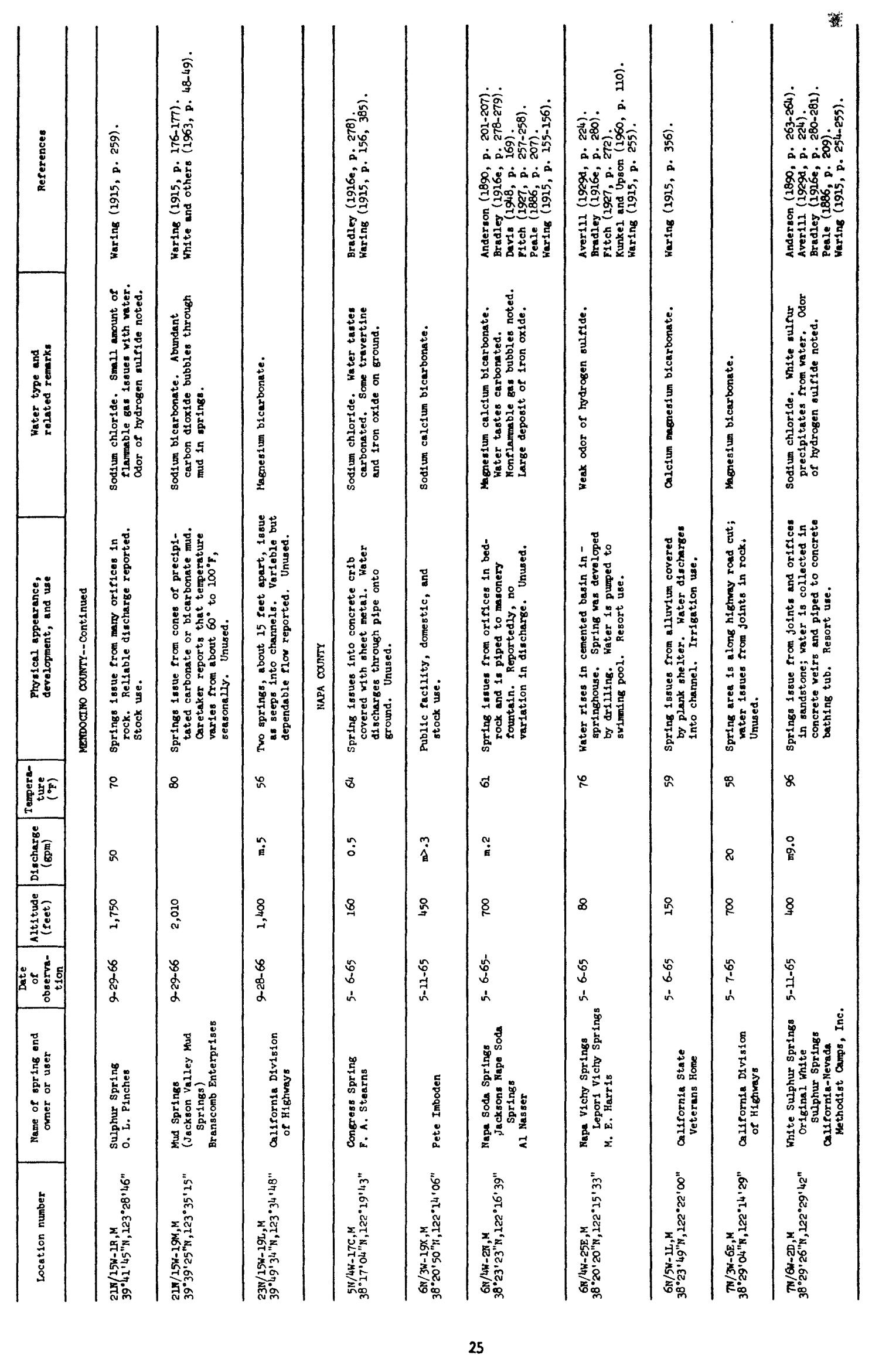




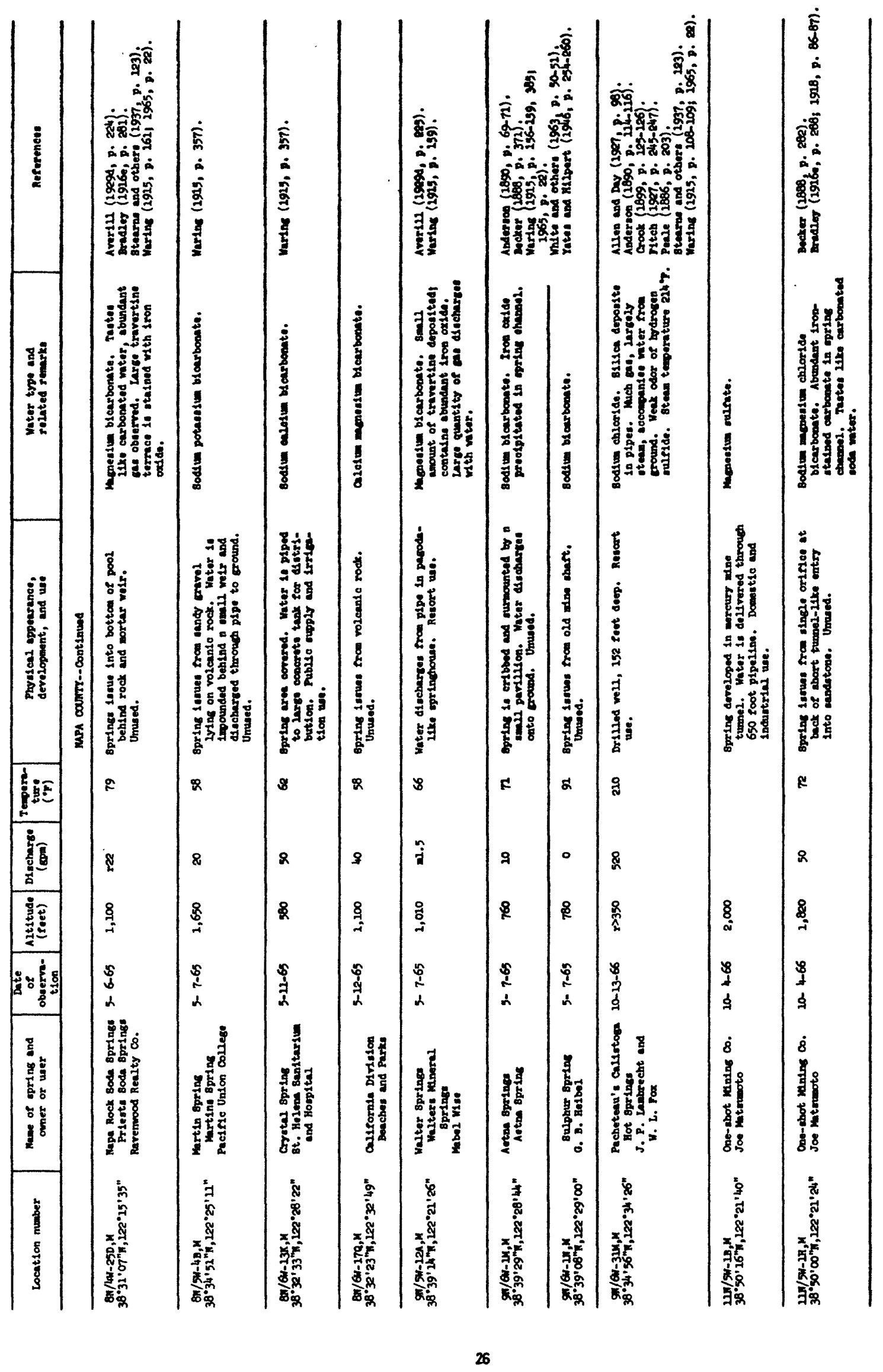




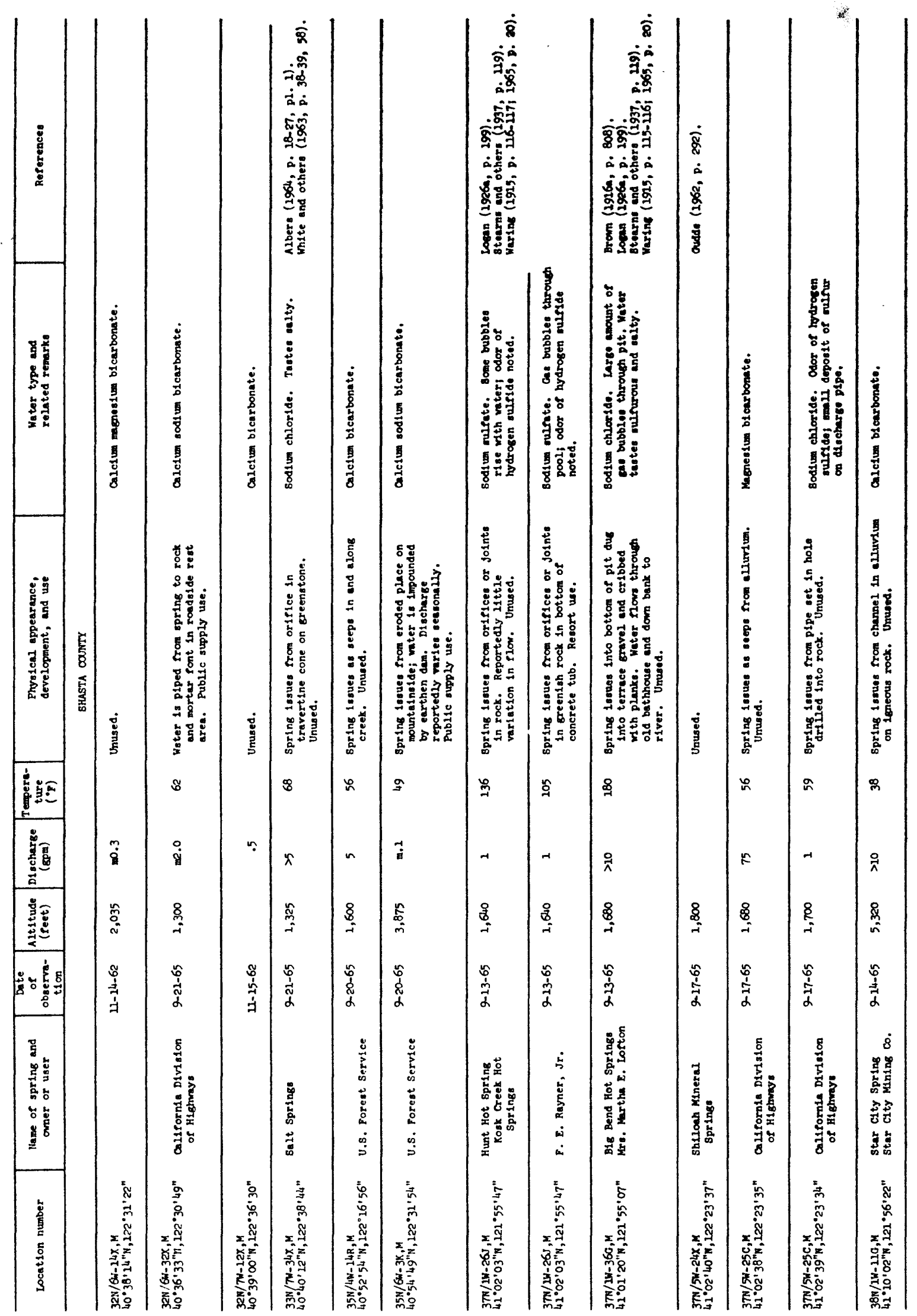




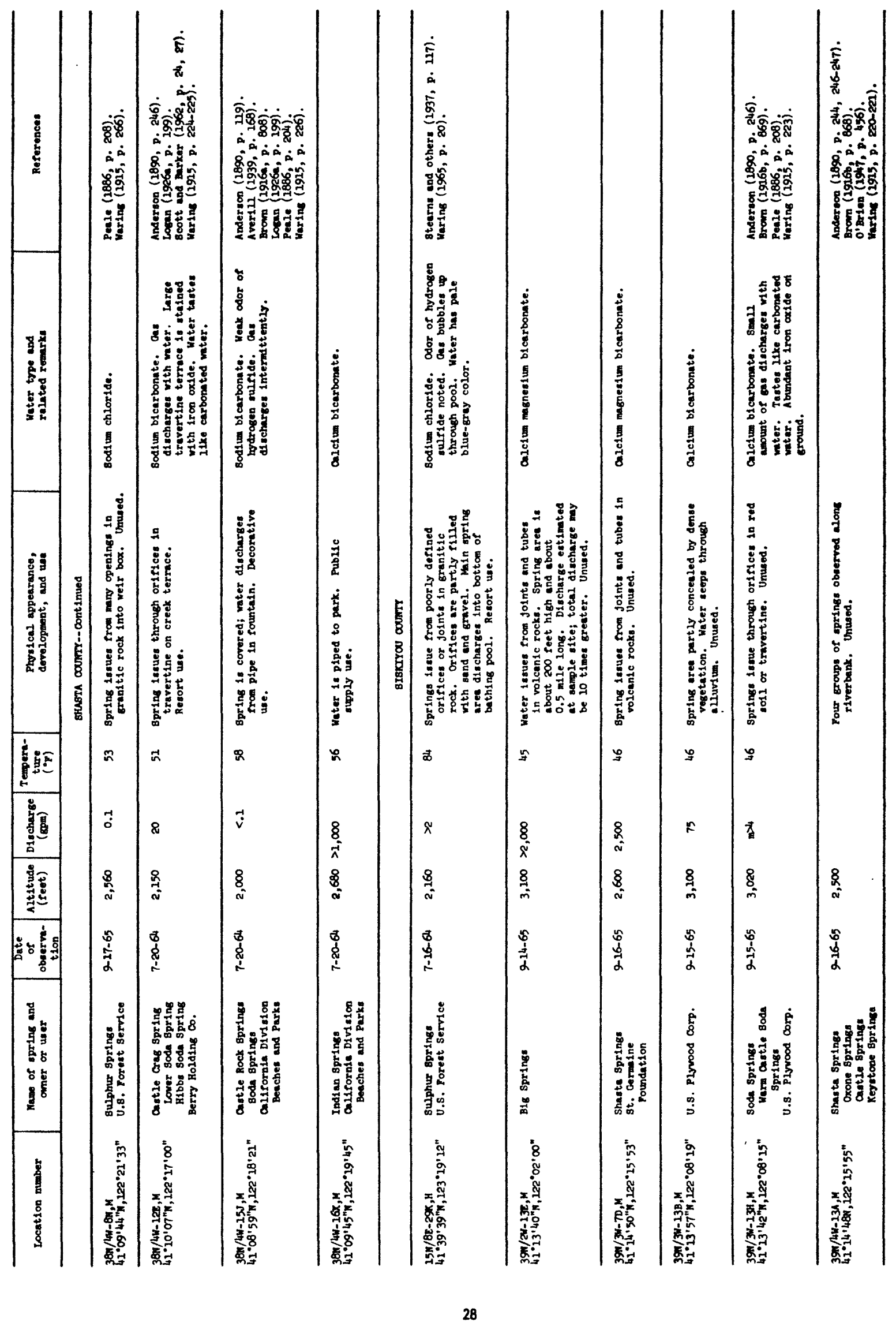




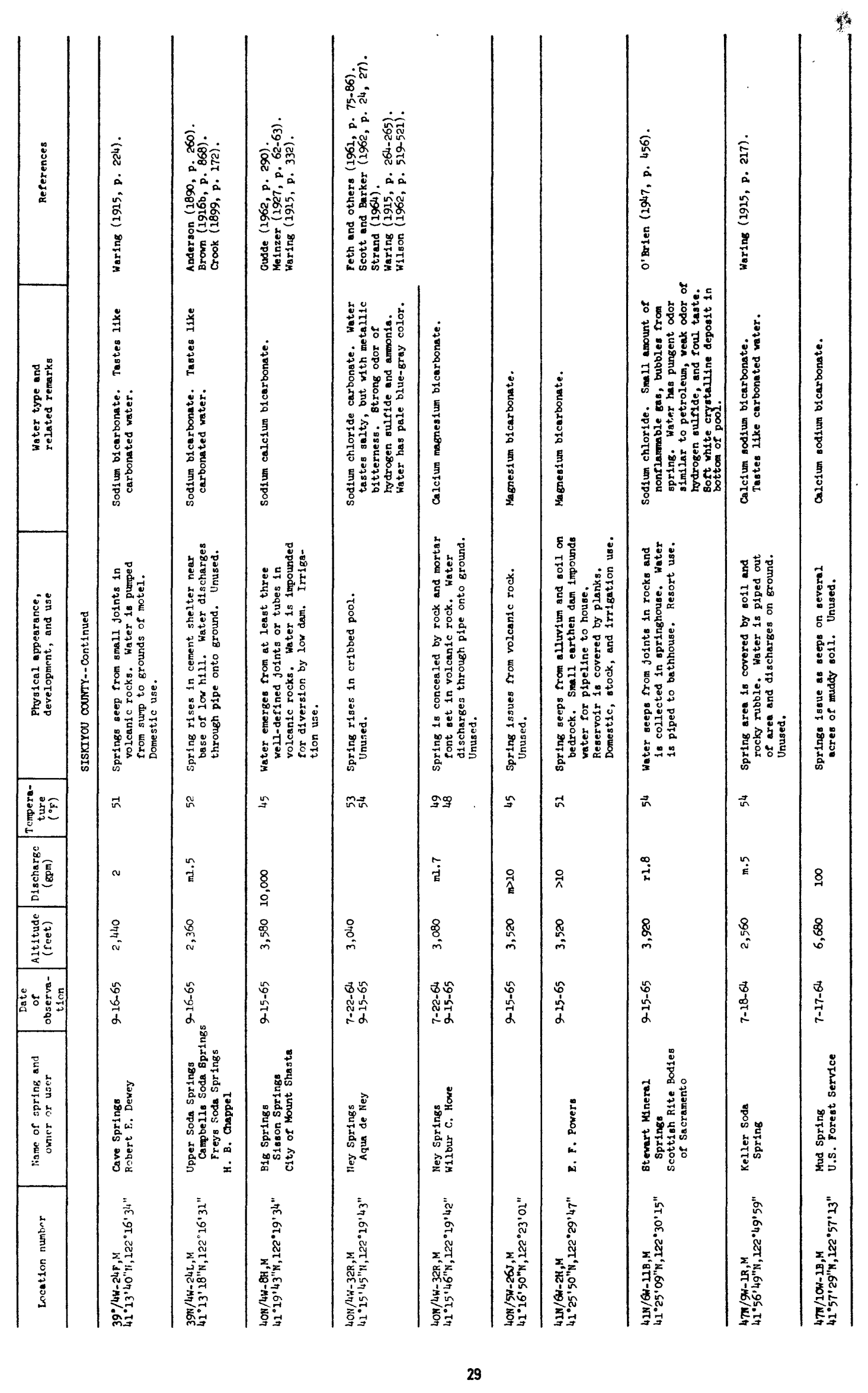




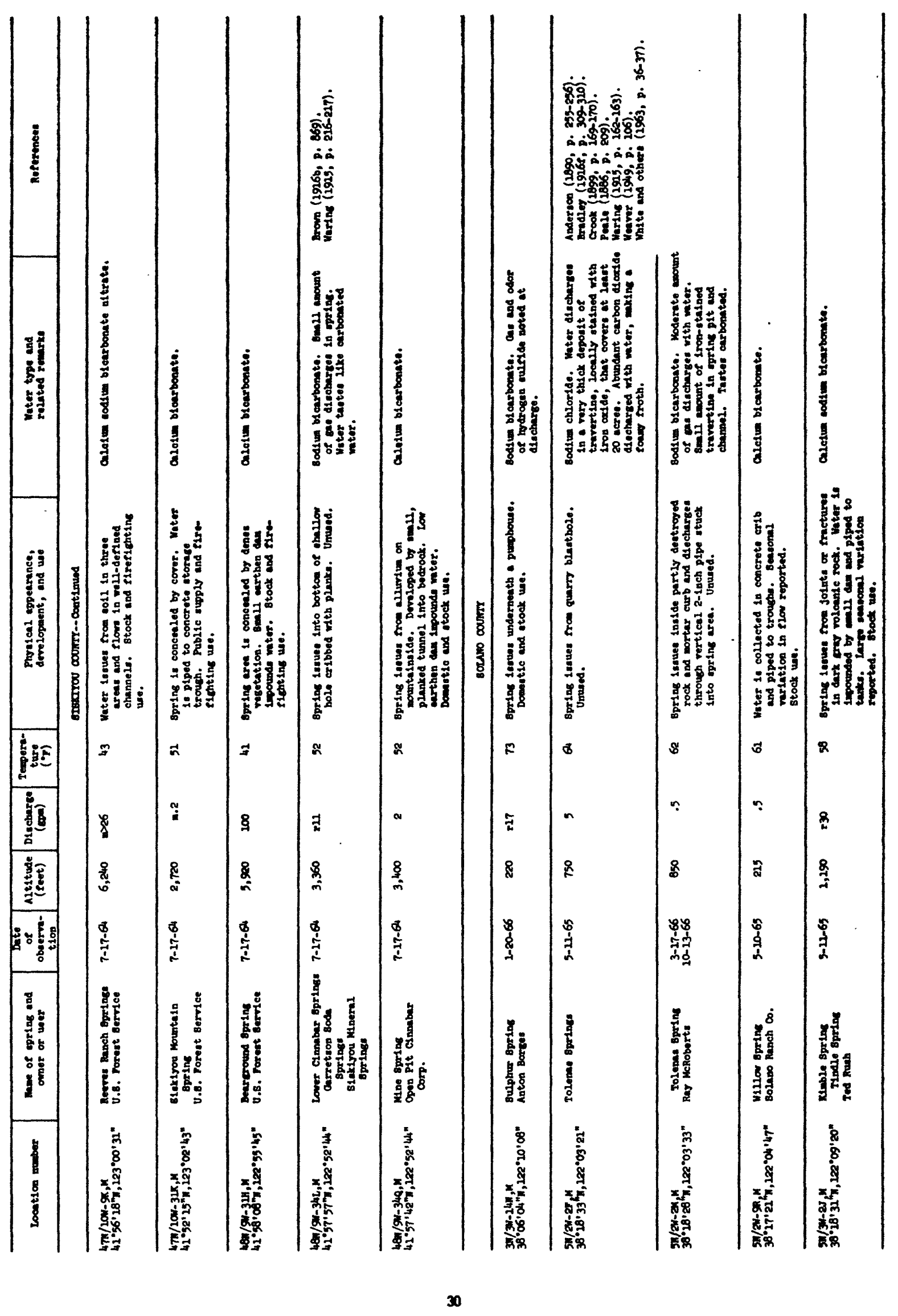




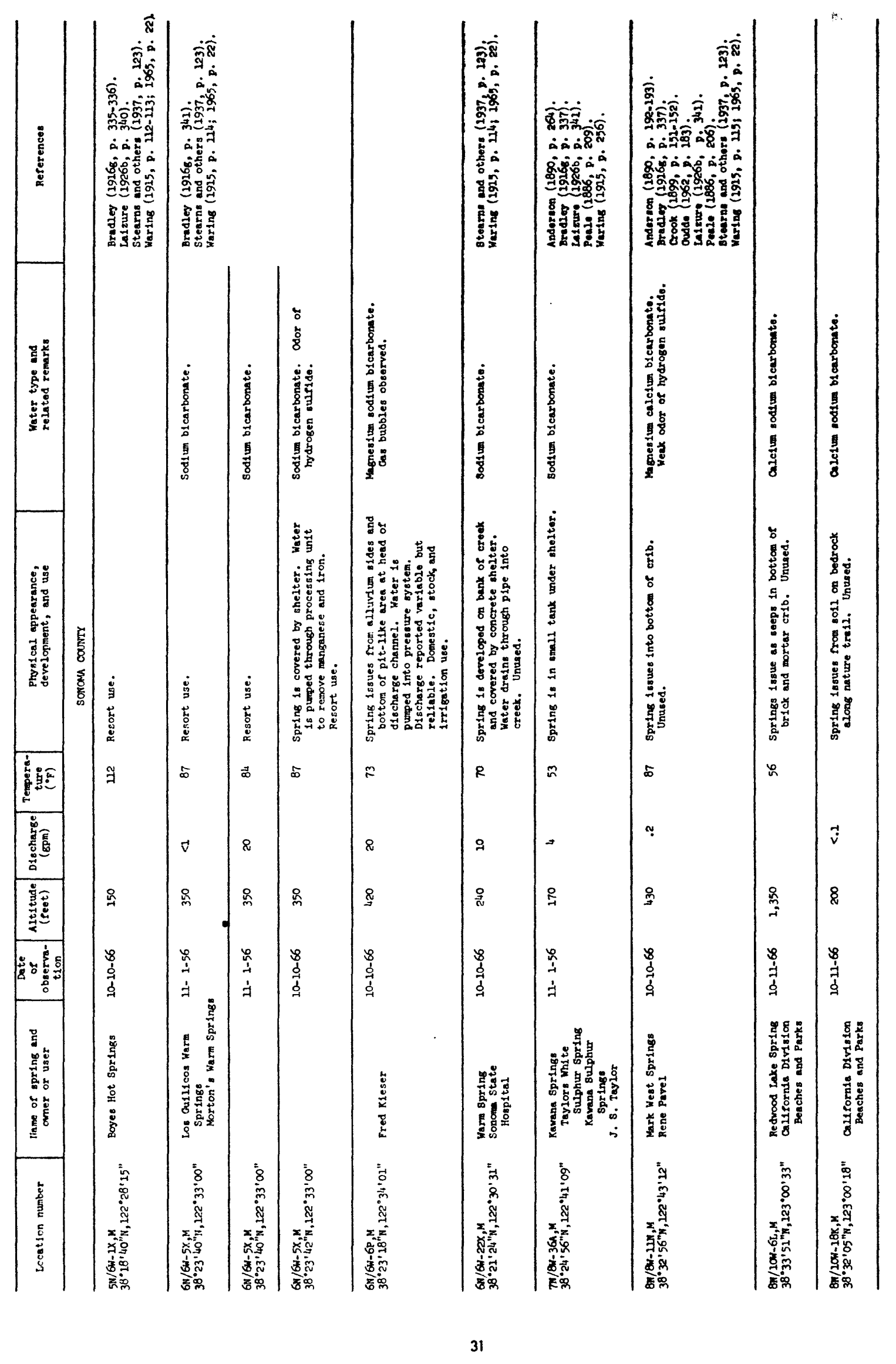




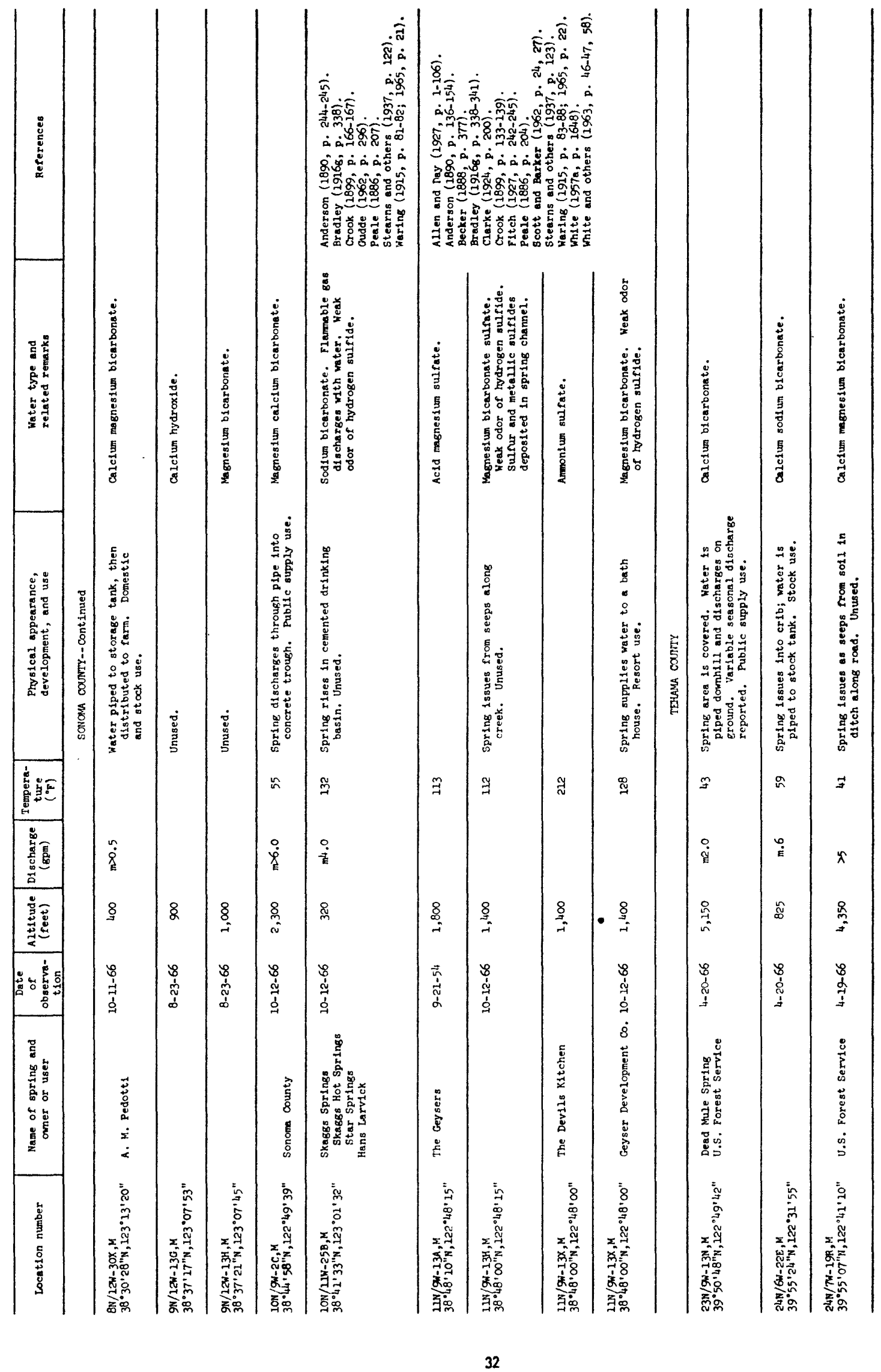




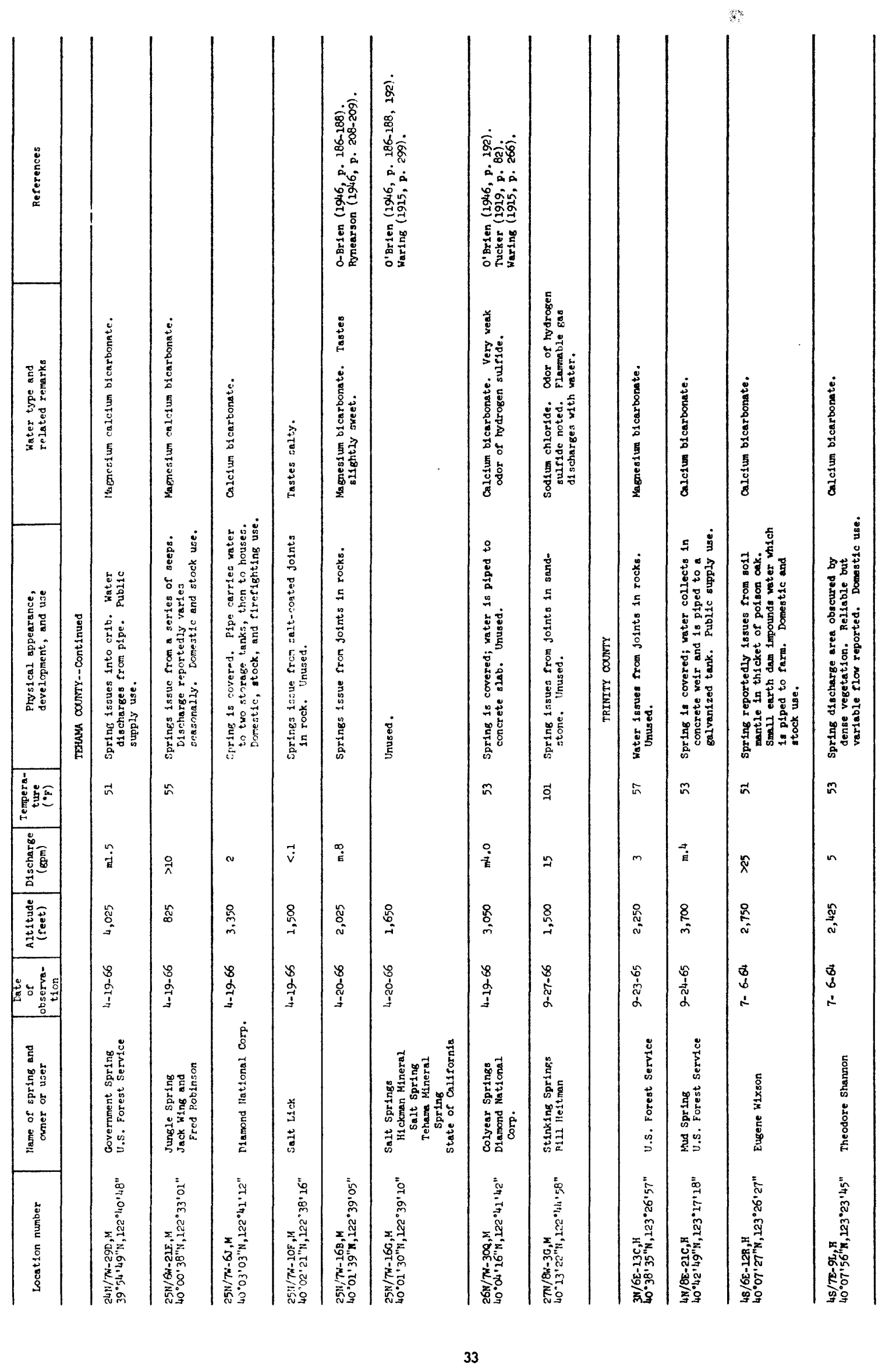




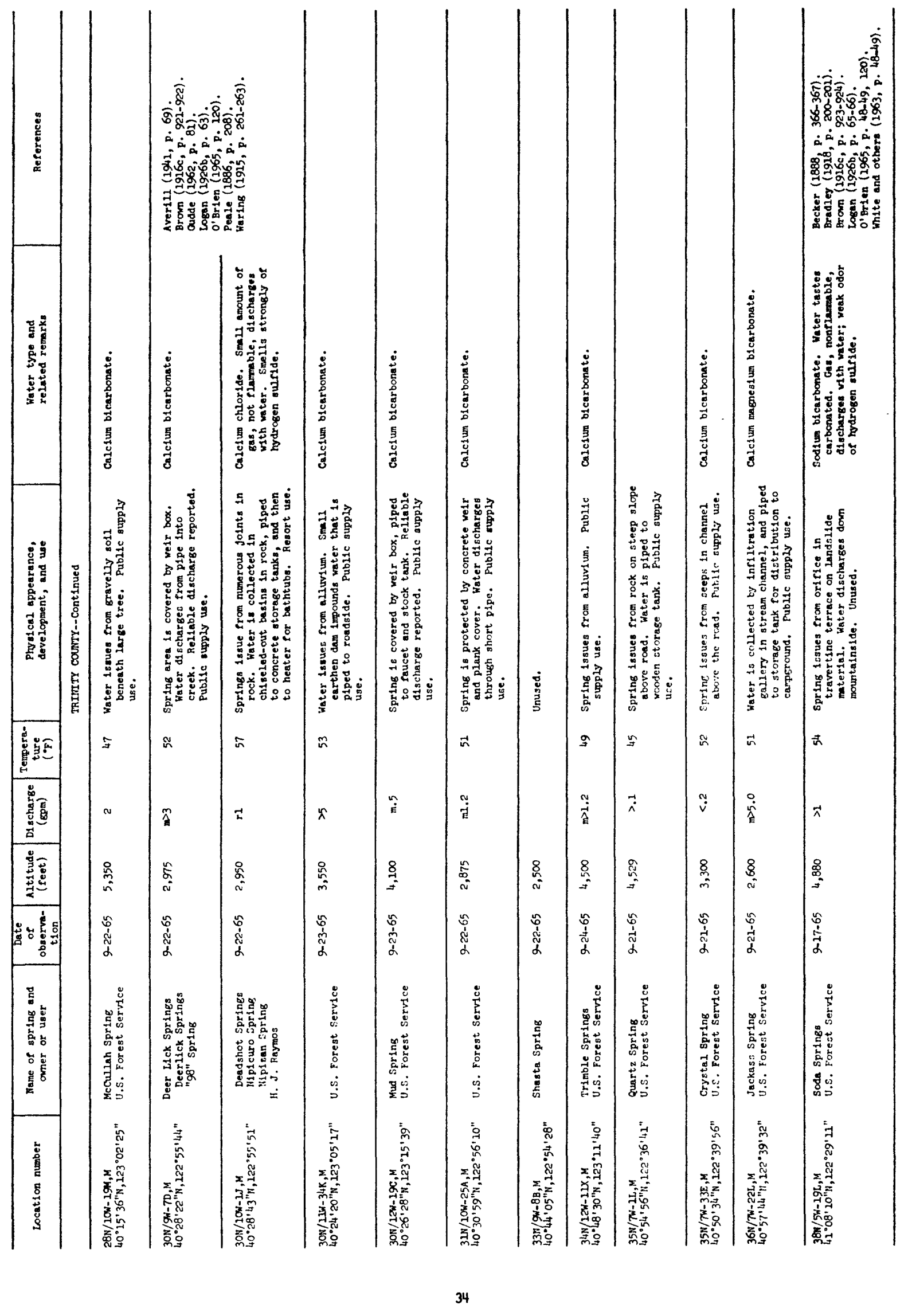




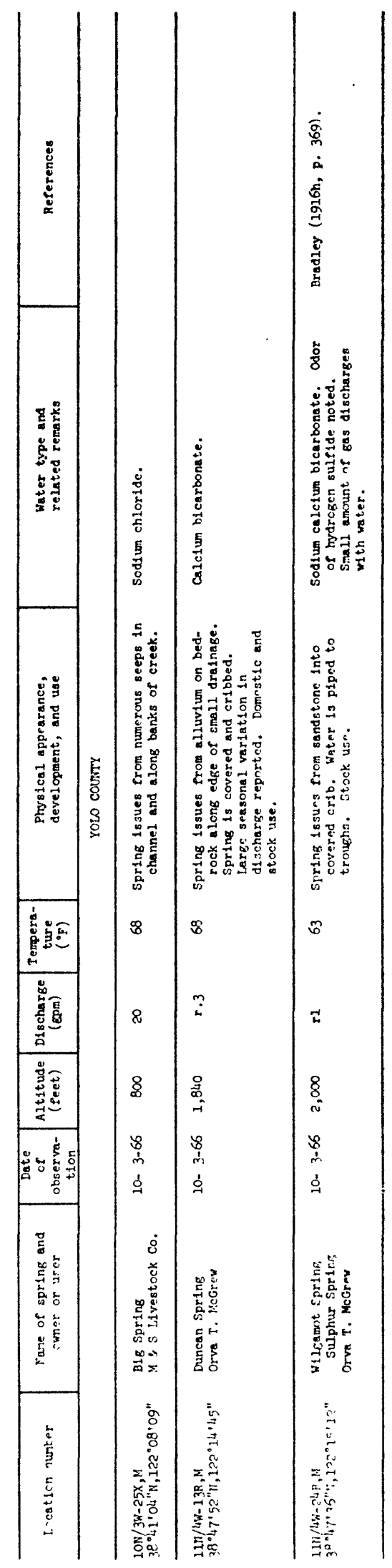




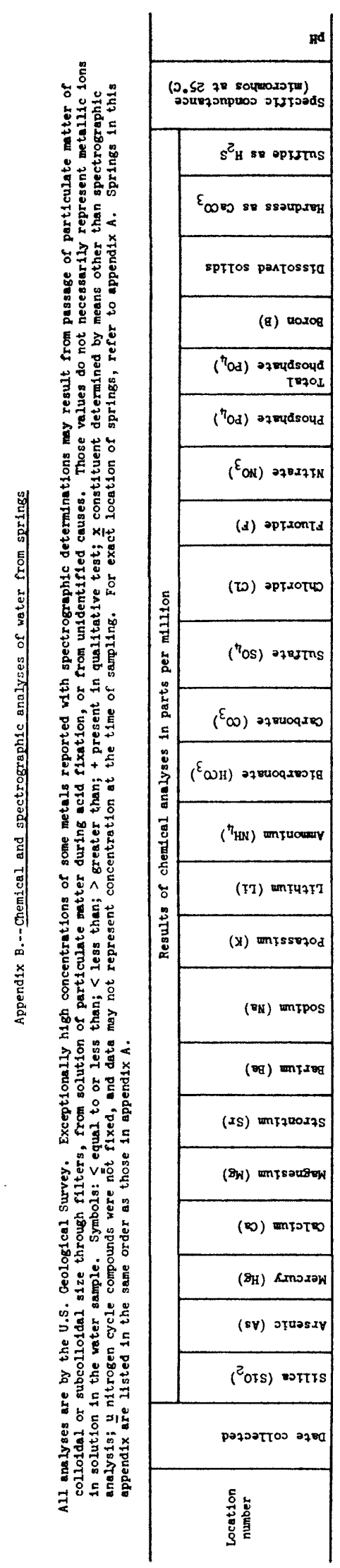

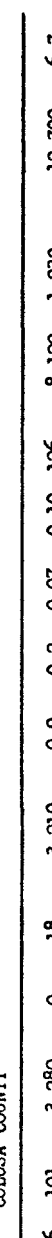

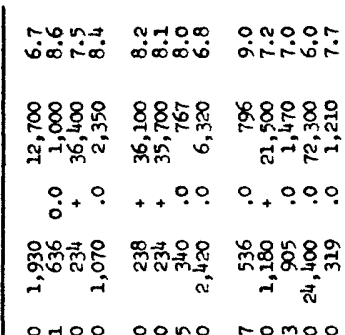

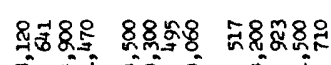

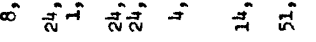

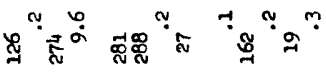

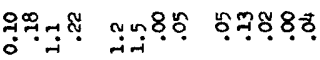

ธำำำ

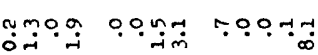

ํำ

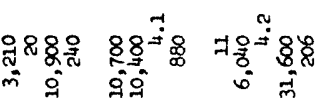

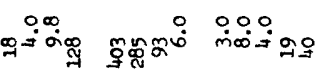

omog 0000 K0000

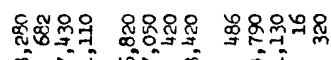

$\circ \div 0 \%$

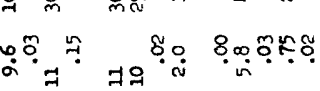

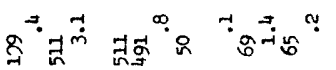

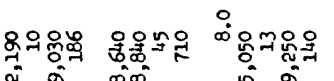

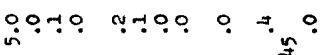

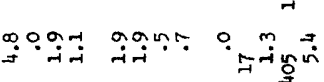

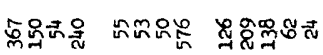

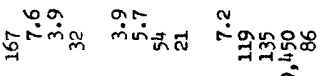

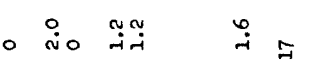

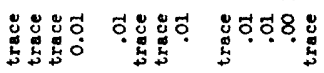

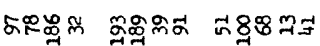

8888888888888

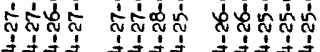

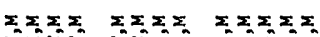

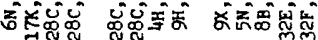

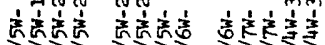

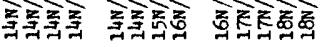

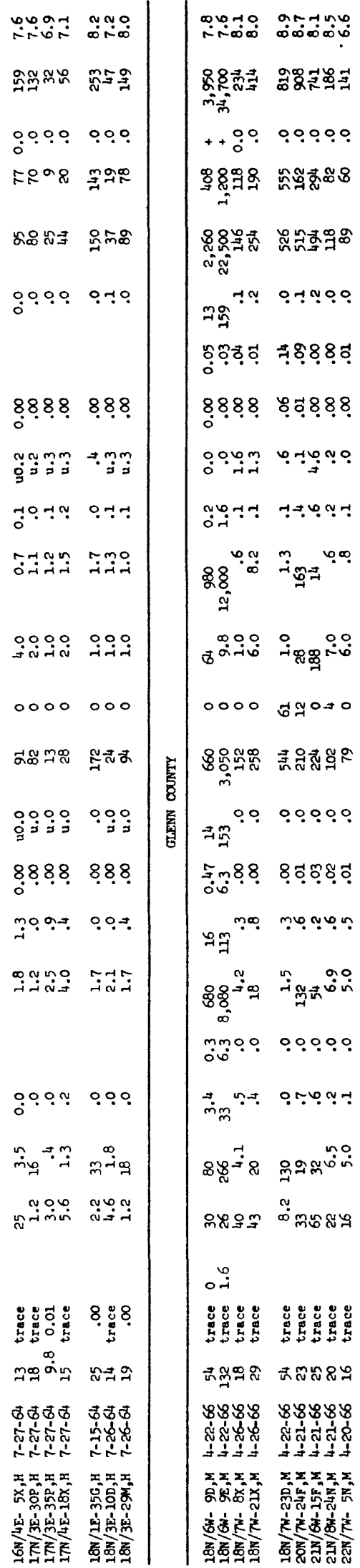




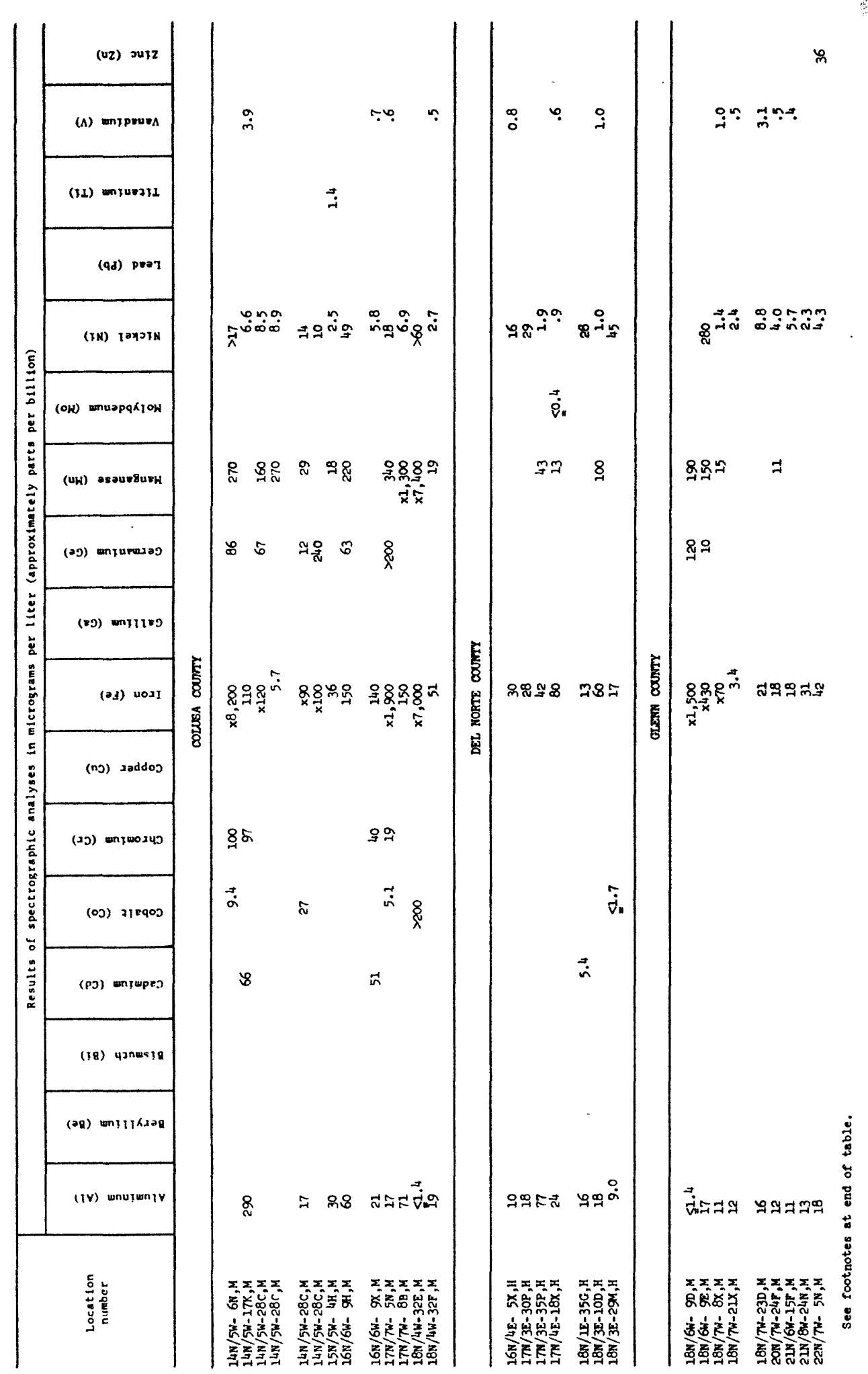




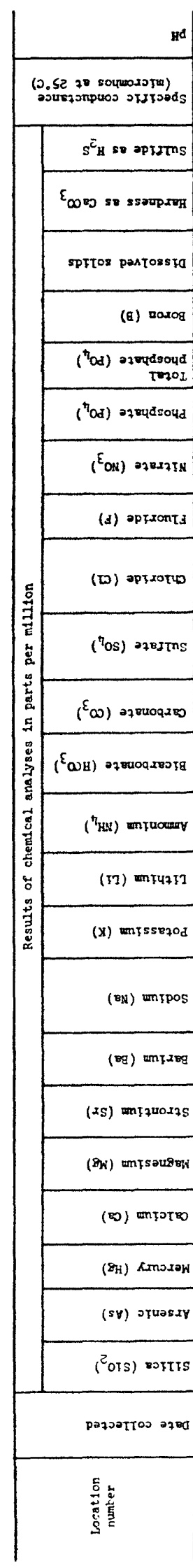

$\mid$

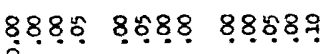

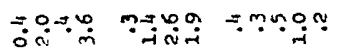

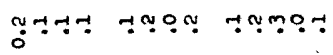

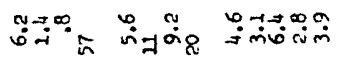

ㄱำ

7010000000000

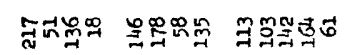

$0.000 .0000 \quad 00000$

8988. 89.078 898889

ד.

뭄ำ

$\rightarrow 000 \quad \div 000 \quad 400004$

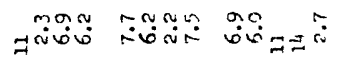

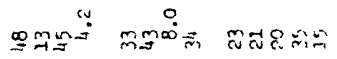

88.

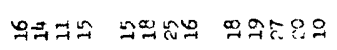

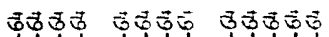

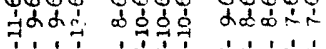

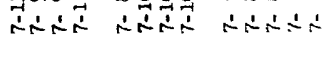

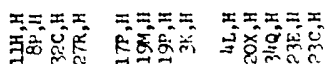

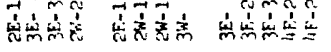

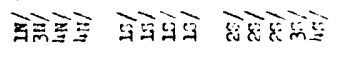

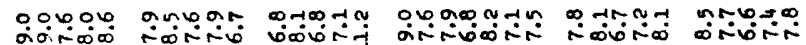

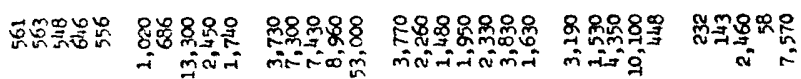

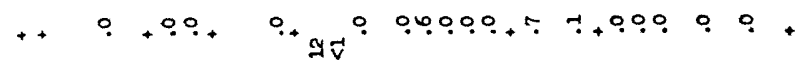

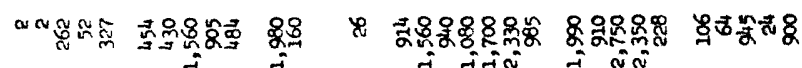

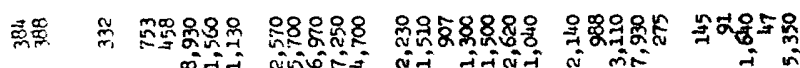

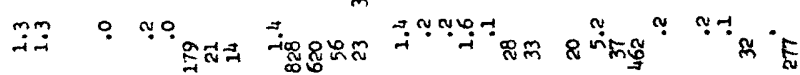
วั0ำ

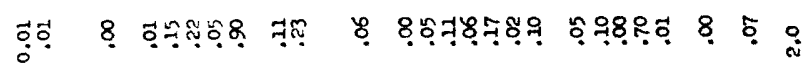

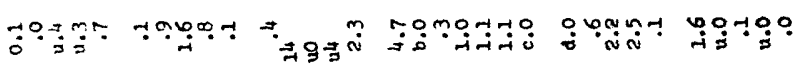
में

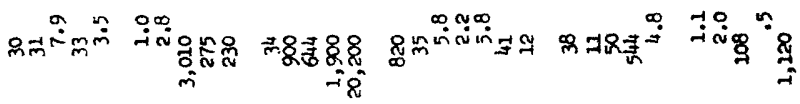

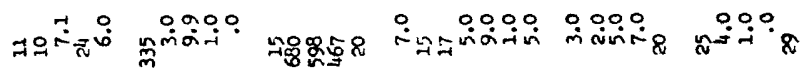

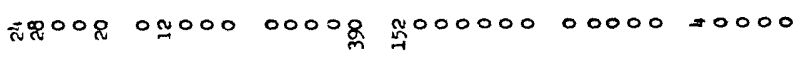

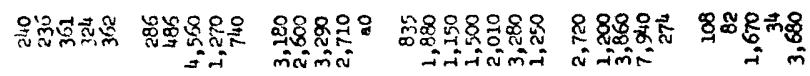

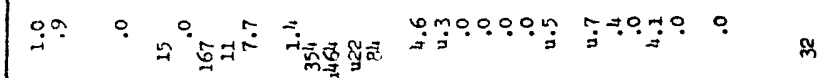

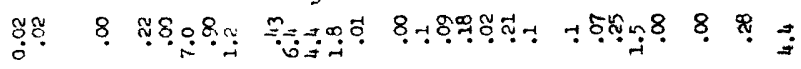

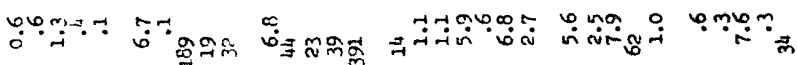

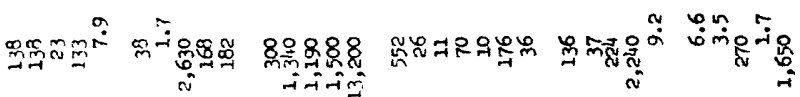

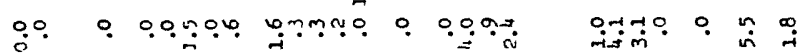

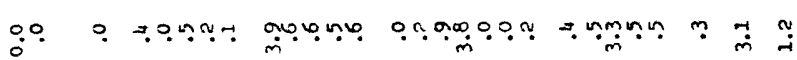

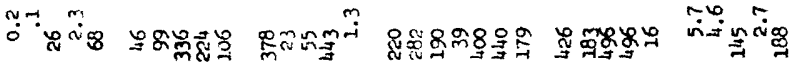

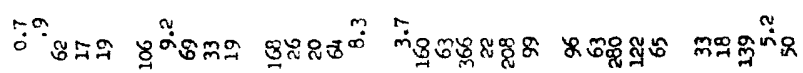

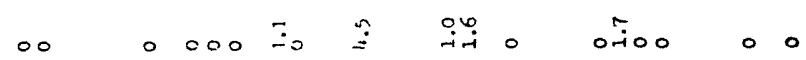

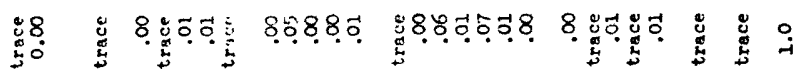
ผ ผ \%860\%

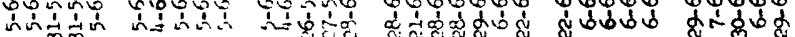

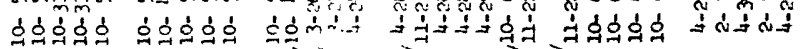
$x=x=x x=x=x y=x$

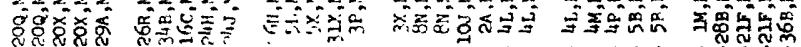

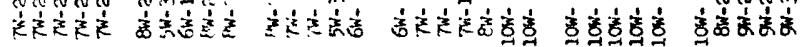

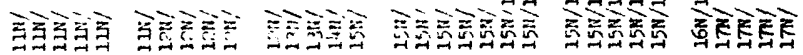




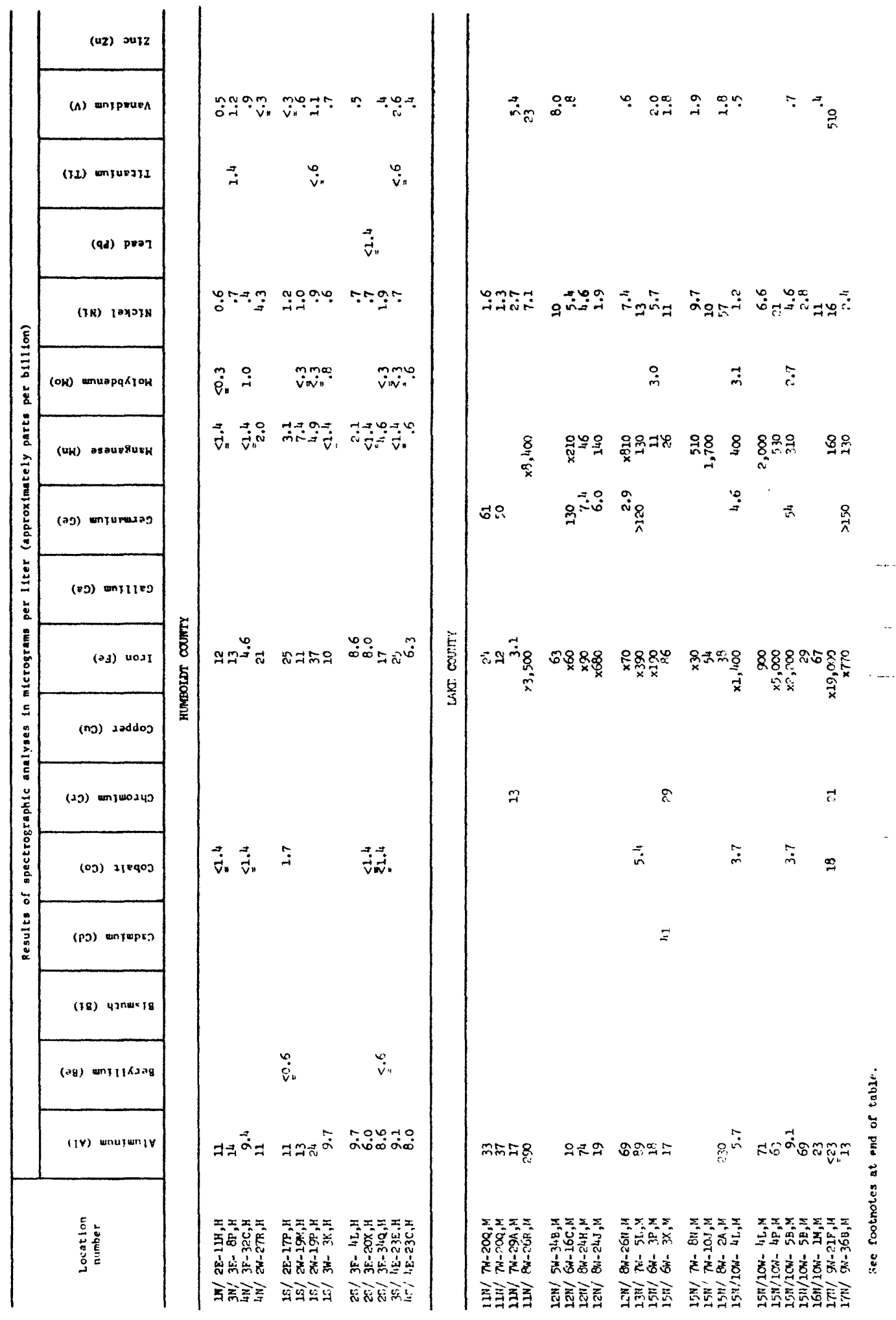




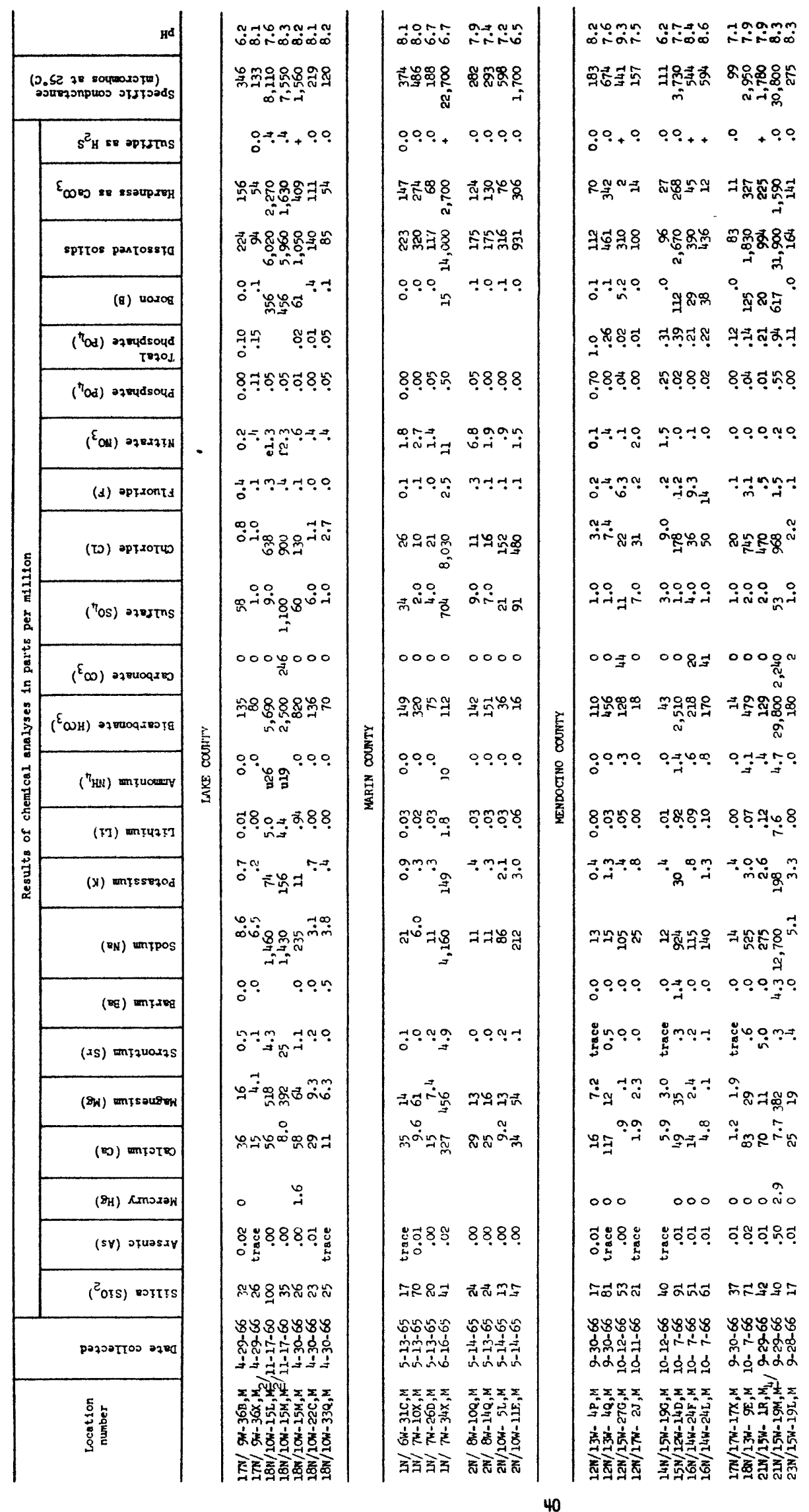




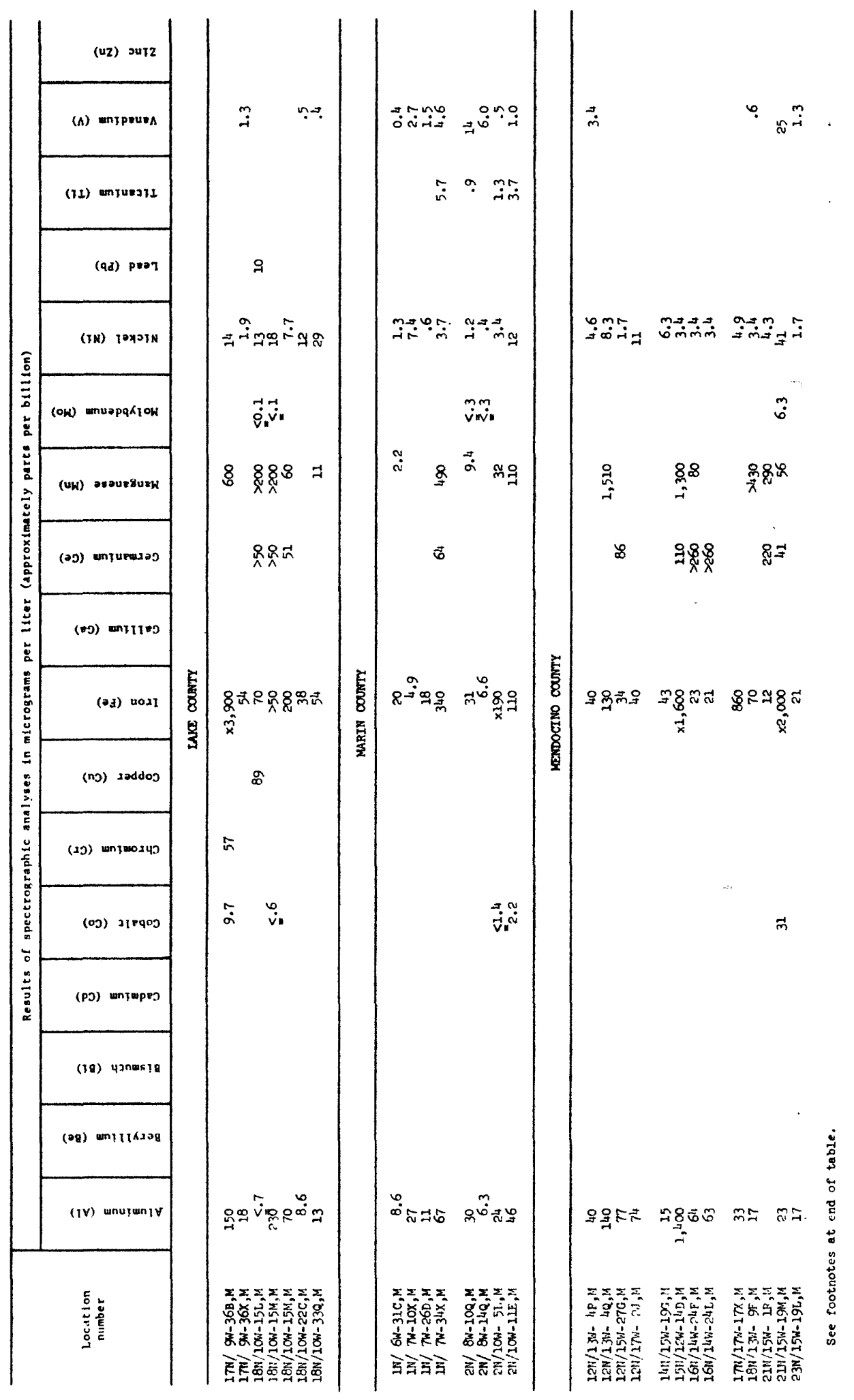




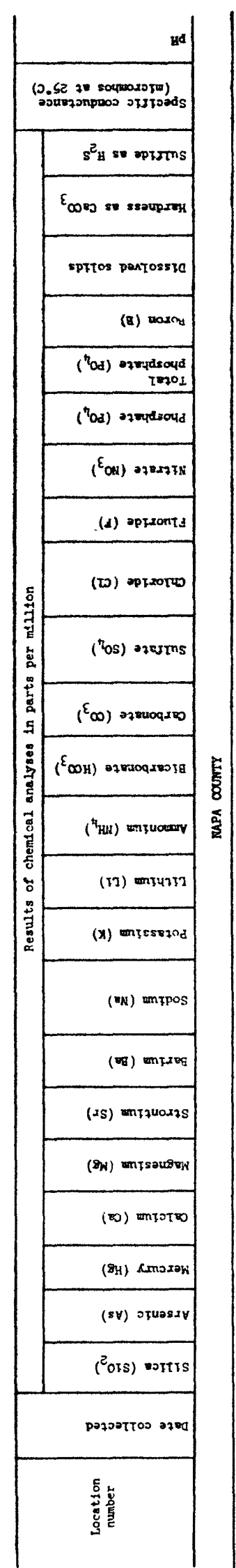

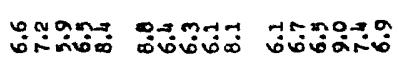

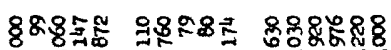

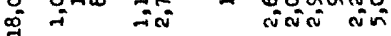

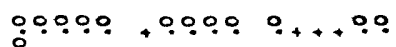

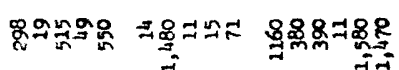

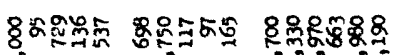

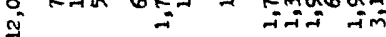

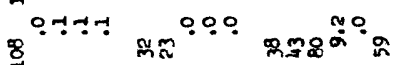
8ุรัต

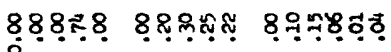

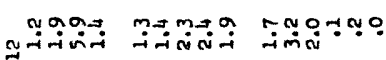

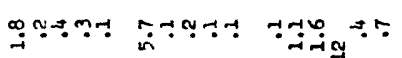
赵

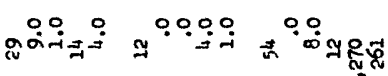
00007 70000 000 尔0

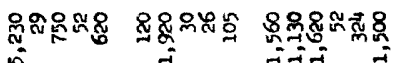

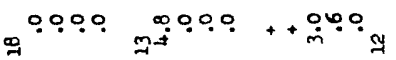

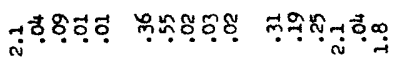

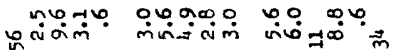

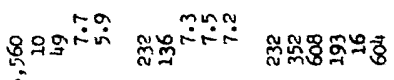

צִ

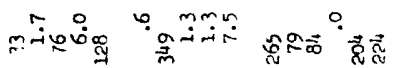

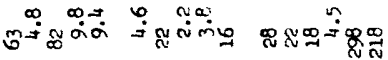
000

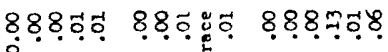

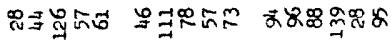

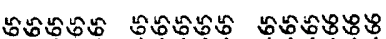

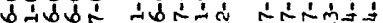

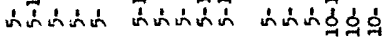

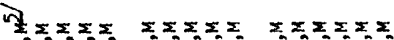
0.

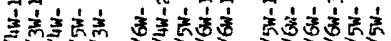

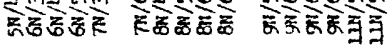

ำำ

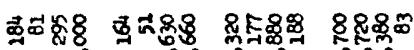

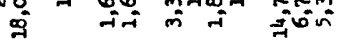

o $+99++9+9+9+9$

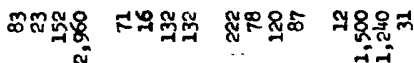

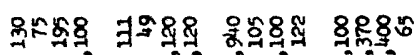

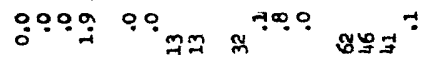

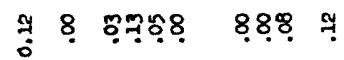

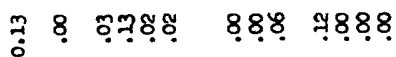

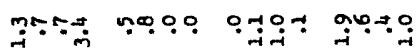

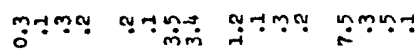

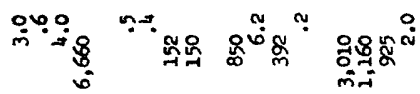

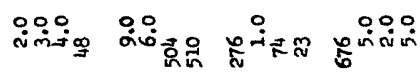

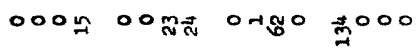

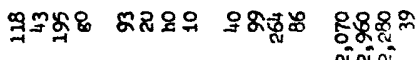

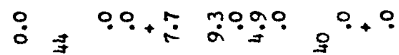

范

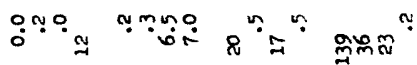

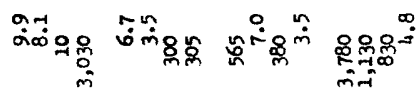

:

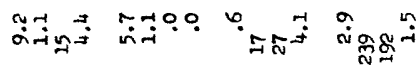

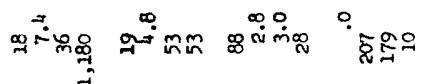

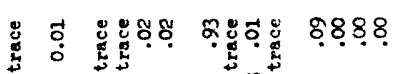

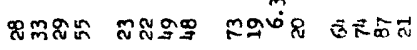

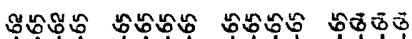

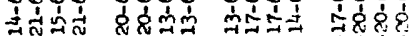

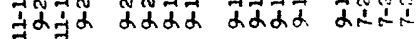

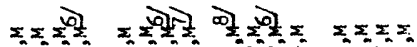

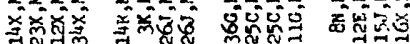
通遂定定

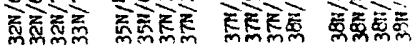




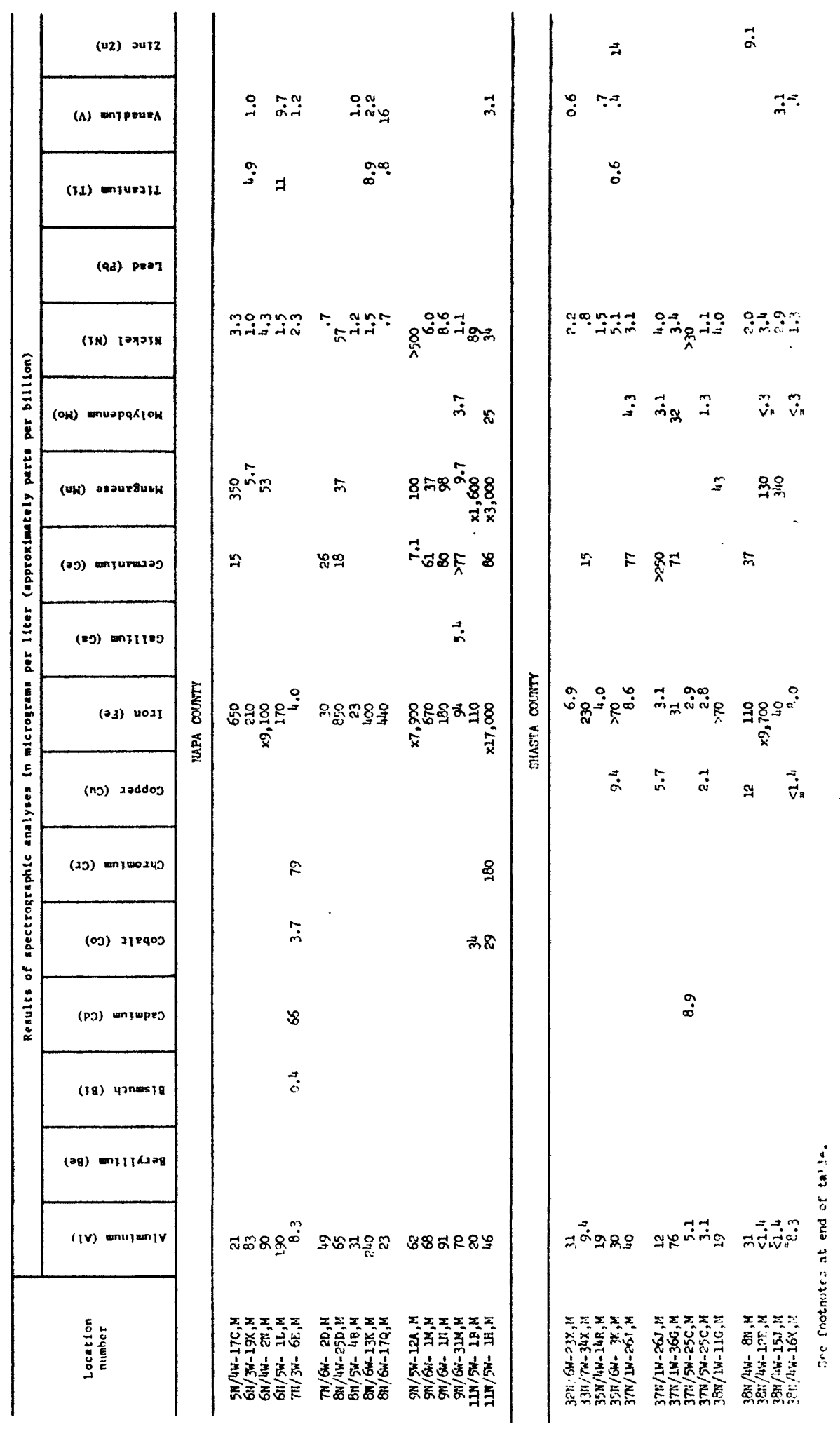




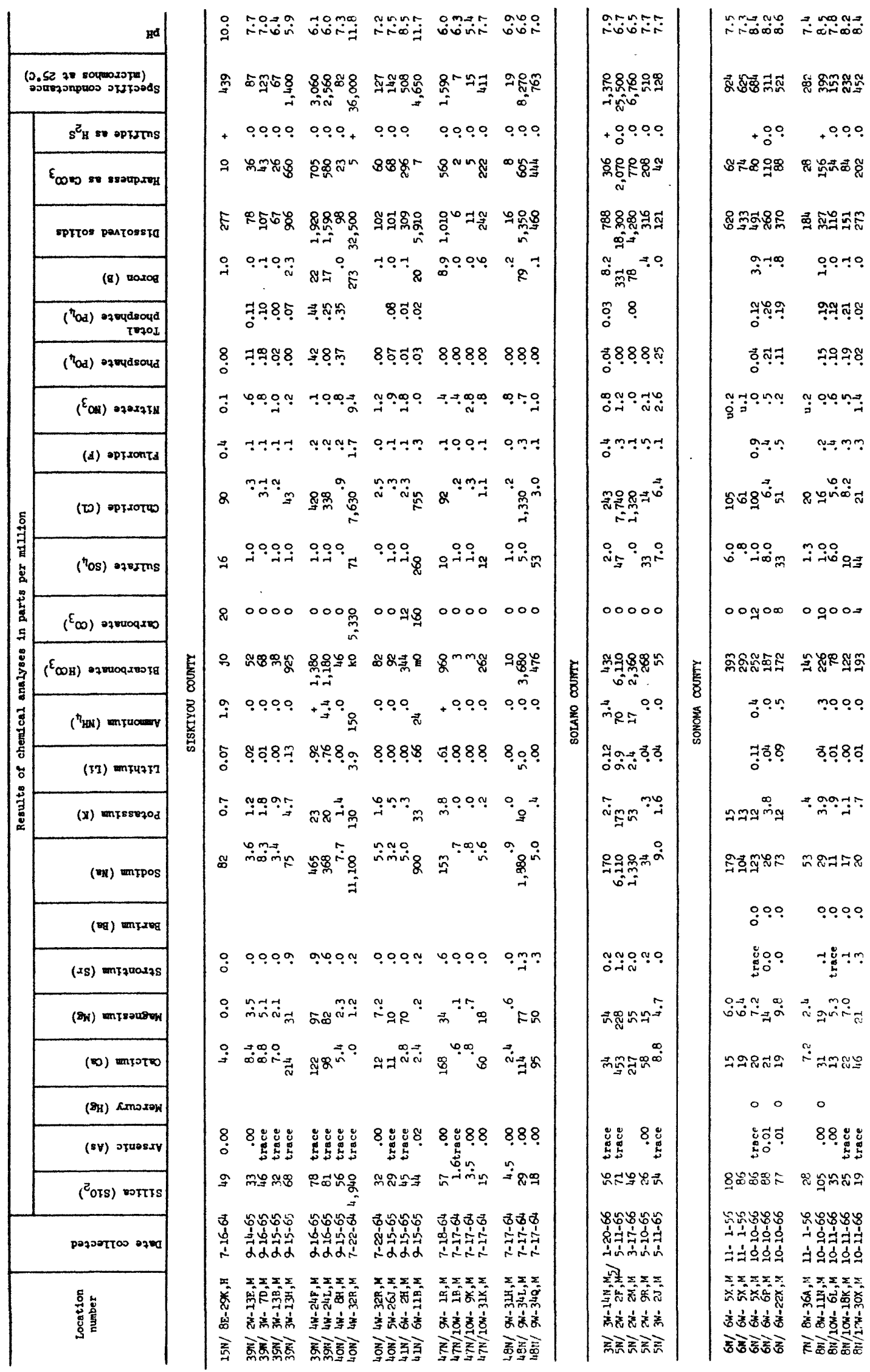




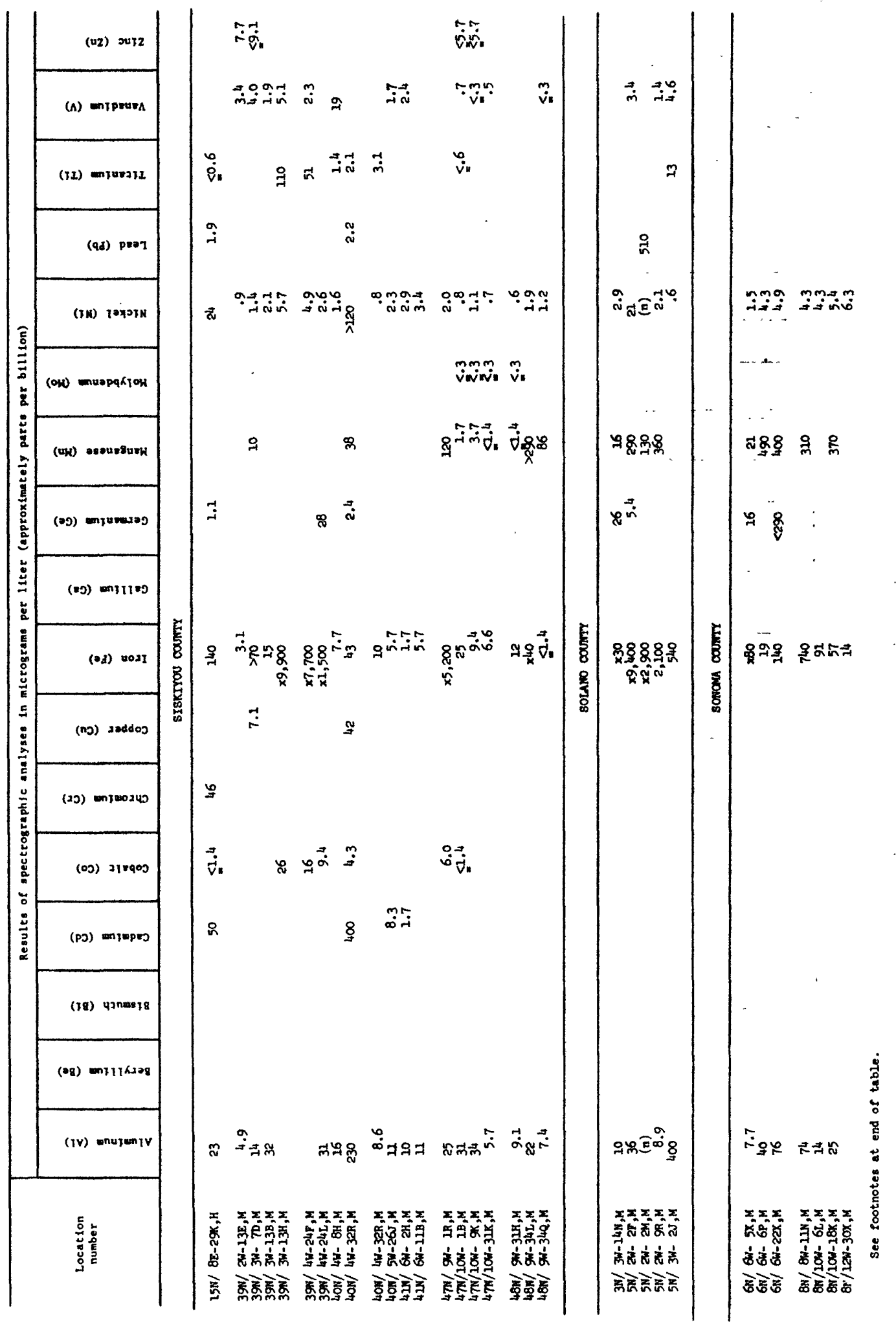




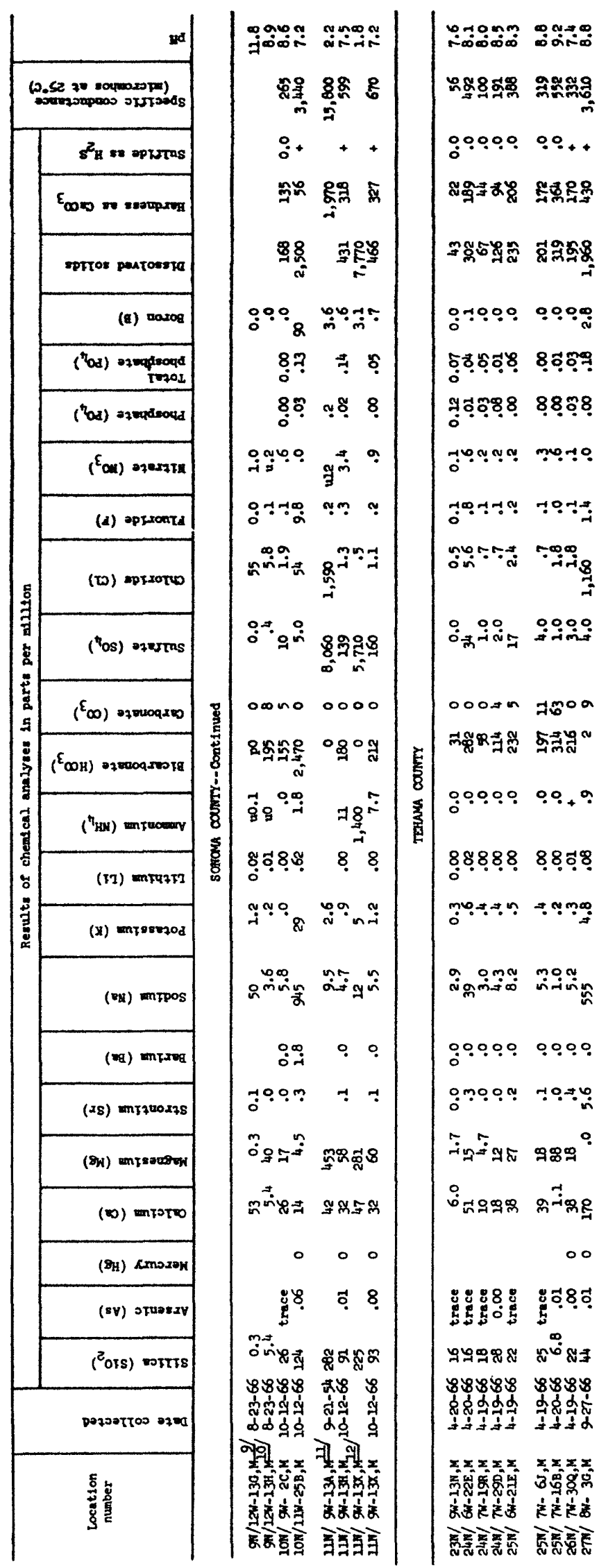

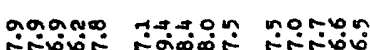

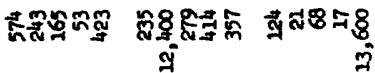

000099.90909009

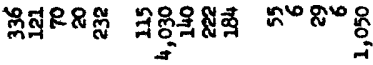

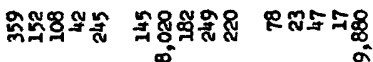

:

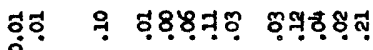

ชั่0

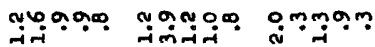

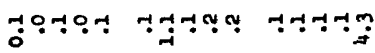

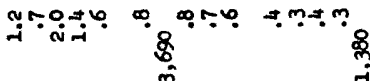

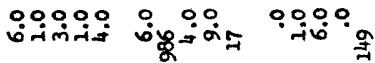

$00000 \quad 08=00 \quad 00000$

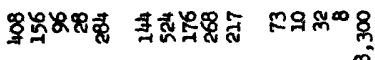

웅

$88889898888 \quad 898 \%$

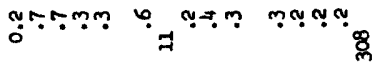

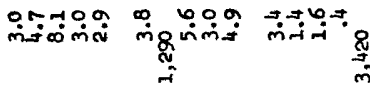

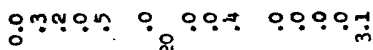

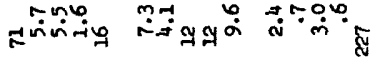

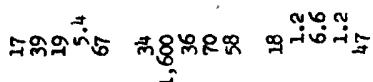

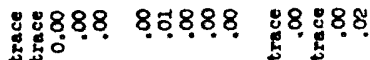

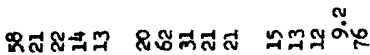

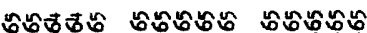

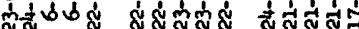

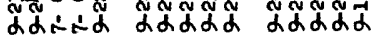

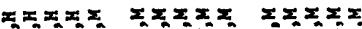

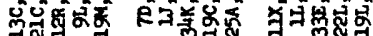

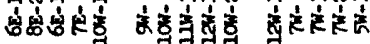

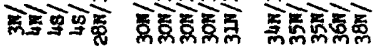




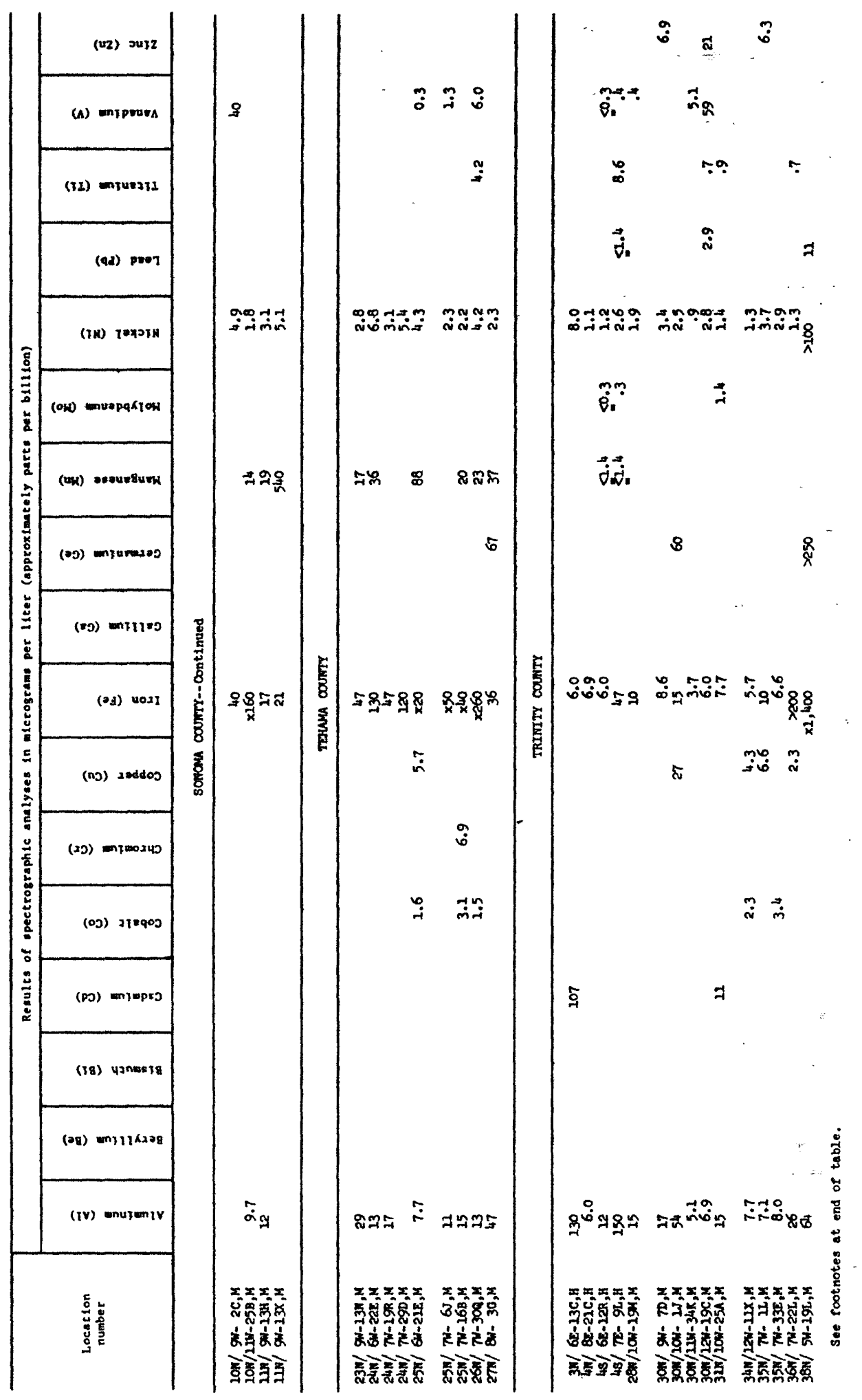




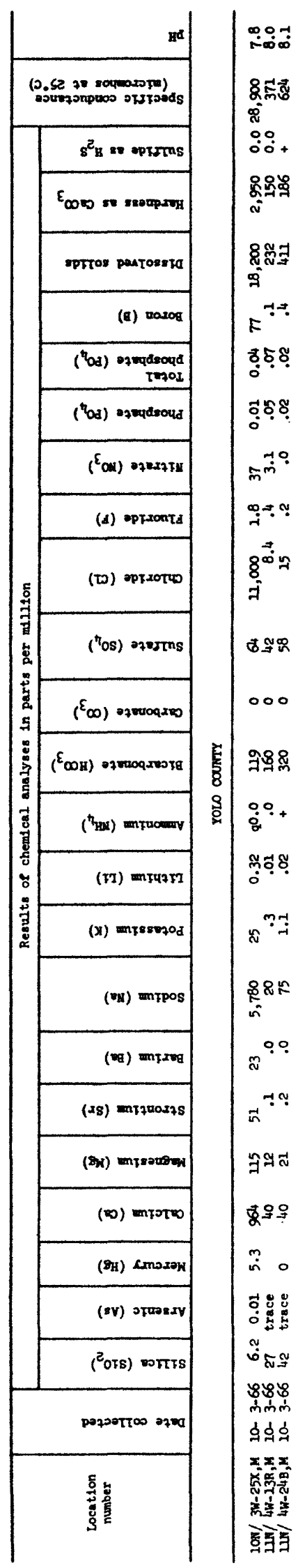




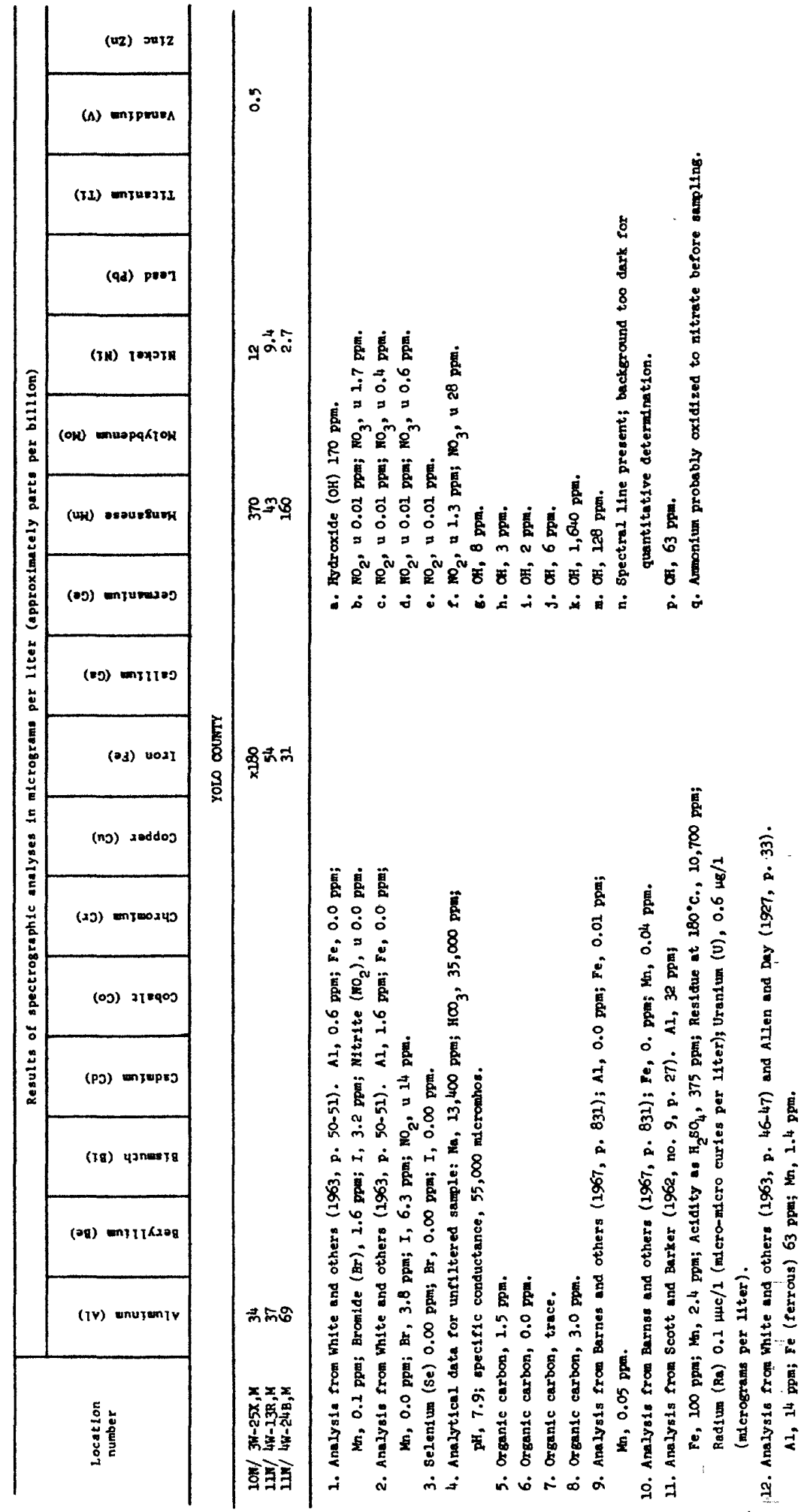

